\title{
Magma mixing in Neoarchean granite from Nalgonda region, Eastern Dharwar Craton, India: Morphological, mineralogical and geochemical evidences
}

\author{
Soumya Shukla ${ }^{1}$ and M Ram Mohan ${ }^{2} *_{\infty}$ \\ ${ }^{1}$ Academy of Scientific and Innovative Research, National Geophysical Research Institute, \\ Hyderabad 500 00\%, India. \\ ${ }^{2}$ CSIR-National Geophysical Research Institute, Hyderabad 500 00\%, India. \\ *Corresponding author. e-mail: rammohan@ngri.res.in
}

MS received 12 February 2018; revised 2 July 2018; accepted 8 July 2018; published online 13 March 2019

We present field, petrographic, mineralogical and whole-rock geochemical data for part of the Neoarchean granite and associated microgranular enclaves (MEs) occur in the Nalgonda region, NE part of Eastern Dharwar Craton (EDC), and demonstrate the end-member magma mixing processes in the petrogenesis of the host granite. Extensive occurrence of ME and uni-directional flow band structures (N-S trend) in all the studied outcrops exposed over about $20 \mathrm{~km}$ depict that intensive magma mixing-mingling occurred at magma chamber scale. MEs are the portions of intermediate mafic magma that had interacted at two stages with acidic host granite. Mixing at the initial stage promoted efficient thorough mixing which resulted in rapakivi texture and mesocratic enclaves. Wispy filament structures around these enclaves indicate that mafic magma globules were mechanically diluted in the host granite magma by chaotic advection. These filamental magmas were further linearly diluted along with convection-related flow of the host magma. Smaller mafic globules also got linearly stretched along with this flow. Upon solidification of the host magma, these wispy mafic filaments were preserved as flow structures. The second stage of mafic magma mixing did not promote thorough mixing due to the large viscosity contrast with the host granite magma and preserved their physical entity. These enclaves are melanocratic with sharp boundary and devoid of gradational contact and filament structures around it. They characteristically show network of granitic vein injection which often show crenulation folding. These evidences indicate that during the second-stage interaction, the enclave magma was rigid to plastic nature with respect to the host granite magma. Coherent linear Harker variation trend of $\mathrm{CaO}, \mathrm{MgO}, \mathrm{TiO}_{2}, \mathrm{~K}_{2} \mathrm{O} / \mathrm{Na}_{2} \mathrm{O}$, $\mathrm{V}, \mathrm{Y}$ and Sc indicates that mixing has promoted to develop chemical gradient between ME and host granite magmas. Mechanical dilution by chaotic advection must have enhanced the chemical diffusion of both magmas. Smooth decreasing Harker trend of Y content in both the magmas indicates that theyhad undergone certain degree of fractional crystallisation. In contrast, elements like Rb, Ba and Sr with large value of diffusion coefficient $(D)$ show scattered behaviour in element-element plots suggesting that diffusive fractionation was active during chaotic advection mixing. It is concluded that heterogeneity in compositional variation of Nalgonda granite can be attributed to difference in degree of mechanical dilution of mafic magma, fractional crystallisation and diffusive fractionation. The geochemical evidences indicate the role of subduction in the evolution of these rocks.

Keywords. Magma mixing; microgranular enclave; granite; Eastern Dharwar Craton. 


\section{Introduction}

In general, the crust formed during Neoarchean time was predominantly constituted of granitoids with diverse mineralogical, geochemical and source characteristics (Jayananda et al. 1995; Laurent et al. 2011, 2014; Dey et al. 2017). Mixing of magmas of distinct composition plays a vital role in generating compositional diversity in the granitoids, particularly mixing with mafic magma (Turnbull et al. 2010; Wiebe and Hawkins 2015). Magma mixing is a complex dynamic process controlled by various factors such as rheology, viscosity, crystallinity and temperature (Barbarin 1990; Perguni et al. 2003; Barbarin 2005). Magma mixing processes can be recognised from outcropscale field evidences (Kumar 2010), micro-textures (Renjith et al. 2014) and geochemical composition (Kumar et al. 2017). Such evidences in turn reflect specific physico-chemical magma processes operated during the mixing. The occurrence of microgranular enclaves (MEs) within the calc-alkaline granitic plutons infers the existence of heterogeneous magma chamber involving the interaction of coeval magmas (Kumar 2010; Jayananda et al. 2014; Elangovan et al. 2017). Such interaction is a dynamic process controlled by different factors such as rheology, viscosity, crystallinity, temperature, etc. (Barbarin 1990, 2005; Kumar 2010; Jayananda et al. 2014; Elangovan et al. 2017) and lead to the formation of MEs, synplutonic mafic dykes and hybrid rocks. Magma chamber processes are best exemplified in granitic plutons in the form of magma mixing, mingling and hybridisation. In this study, we are presenting the field, petrographic, mineralogical and geochemical evidences to establish the existence of magma chamber processes from one of the less-known granitic plutons from the north-eastern part of the Eastern Dharwar Craton (EDC). The variations in the morphological and textural features of the MEs and the host granite reveal about the magma mixingmingling environment.

\section{Geology of study area}

Dharwar Craton (DC) is one of the largest cratonic blocks of peninsular India (figure 1a). Variations in the lithology, age and the grade of metamorphism prompted to divide the DC into the Western Dharwar Craton (WDC) and the EDC (Ramakrishnan and Swaminath 1981). Based on the structural and geochronological studies, it is widely agreed that the thrust zone along the eastern margin of Chitradurga greenstone belt is the boundary between both cratonic blocks (Chadwick et al. 2003; Jayananda et al. 2006; Chardon et al. 2011). The WDC is primarily made of older Peninsular gneissic complex (PGC; 3.3-2.7 Ga; Beckinsale et al. 1980; Meen et al. 1992; Rao et al. 1992) and large greenstone belts that are predominantly composed of metasedimentary rocks and komatiite-tholeiitic volcanic suites (Peucat et al. 1995; Jayananda et al. 2008), whereas the EDC is dominated by calc-alkaline granitoids that are interspersed with thin, linear greenstone belts (Jayananda et al. 2000; Naqvi 2005). Based on the close lithological similarity, structural coherence and emplacement between 2.7 and $2.5 \mathrm{Ga}$, the plutonic complex of EDC was termed as Dharwar Batholith (Chadwick et al. 2000). Tectonic evolution of EDC is a matter debate, with two main end-member hypotheses involving vertical and horizontal tectonics (Jayananda et al. 2000, 2013; Mohan et al. 2013). Gold mineralisation is mainly confined to the EDC, and the mineralisation event is synchronous with the granitic magmatism (Sarma et al. 2011).

Nalgonda region lies in the north-eastern part of the EDC (figure 1b) forming an extension to the Hyderabad batholith. The region is predominated with Neoarchean granitoids of various types (Dey et al. 2017). The southern margin forms boundary with the Proterozoic Cuddapah basin. Peddavura greenstone belt $(\sim 2.55 \mathrm{Ga})$, a narrow, linear belt with NW-SE trend and primarily made of amphibolites, occurs close to the southern margin (Jayananda et al. 2013; Rajamanickam et al. 2014). Cross-cutting dykes of Early Proterozoic age occur at many places. Very limited information is available on the nature, petrogenesis and source characteristics of Nalgonda granites.

\section{Field relationships}

Part of Hyderabad granite batholith exposed over $20 \times 10^{2} \mathrm{~km}$ area in and around Nemmani village, lying $10 \mathrm{~km}$ north of Narketpally town in the Nalgonda District, is investigated for this study (figure 1b). In general, the granite exposed in this area is light grey in colour, medium-grained and equigranular rock with clear-cut absence of phenocrysts of any phases. Abundant occurrence of magmatic enclaves (MEs) is an unique feature in 

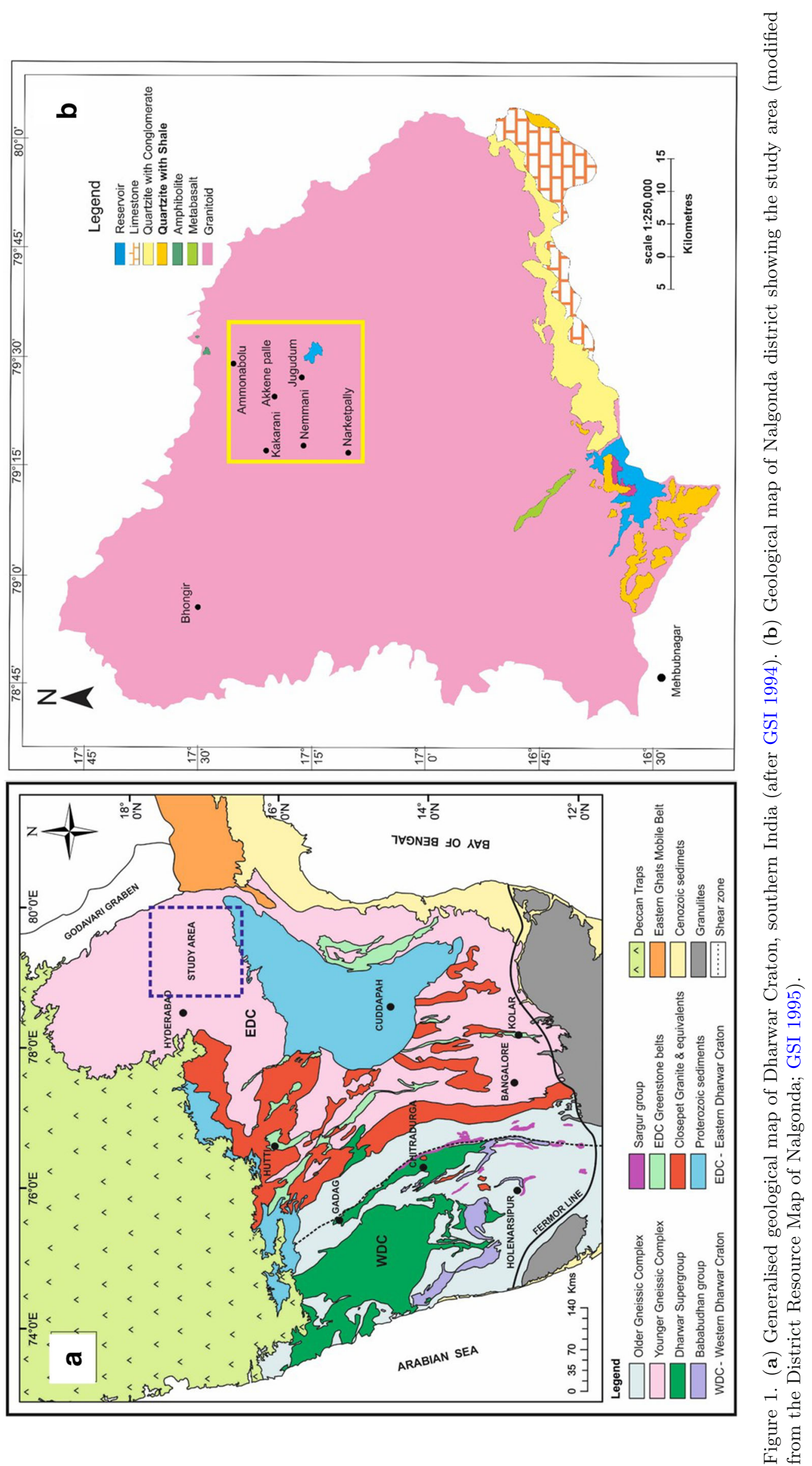

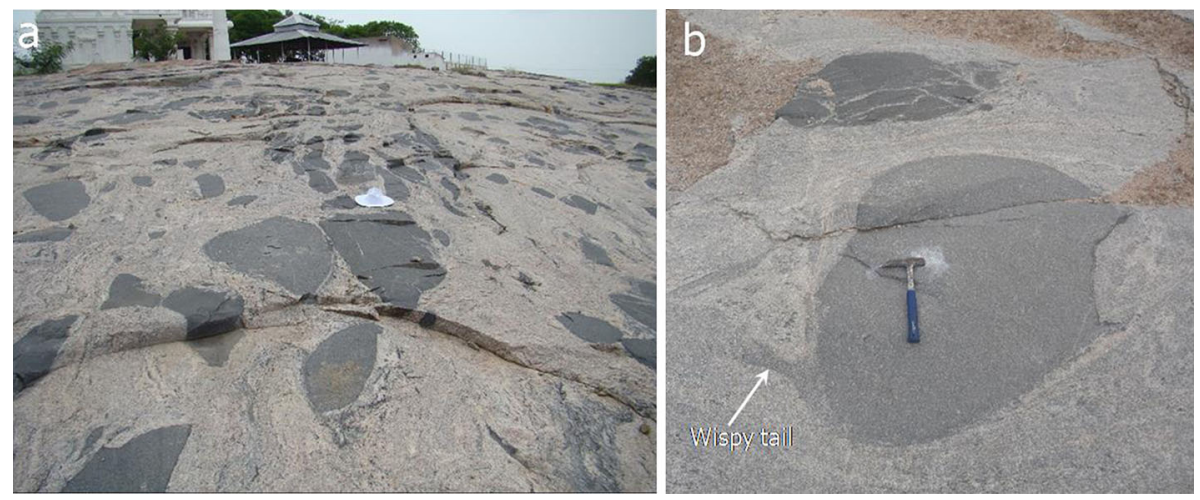

Figure 2. Field photographs. (a) Microgranular enclave (ME) of varying size and shape scattered in the granite near Akenapally village. (b) A sub-rounded large mesocratic ME with wispy tail and cuspate margin. Notice the adjacent melanocratic ME with granitic veins.
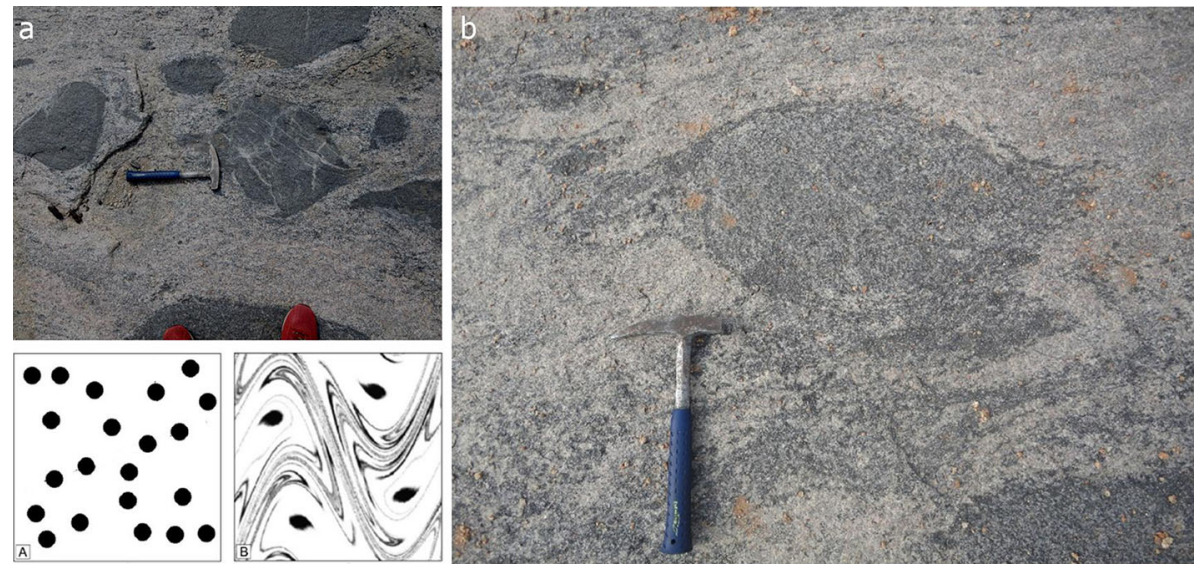

Figure 3. Field photographs. (a) Large- and medium-sized melanocratic ME scattered in the host granite. (b) Mesocratic ME shows diffused boundary and filament-like/patchy mesocratic structure around it. Pictures in (a) and (b) are the 'sinflow' map from Perugini et al. (2003a) visualising the mixing of magmas governed by chaotic advection. In picture (a), the black spots and white background represent mafic magma globules and host felsic magma, respectively. This picture represents the beginning of mixing when physical entities of both the coexisting magmas are clearly recognised. As mixing by chaotic advection get advanced, the globule of enclave magma starts stretching and folding and converts to filament-like structures (see Perugini et al. 2003a, b, and references therein for details). This sin-flow map is compared with the field evidences shown in the field photographs. ME globules are embedded in the felsic host granite as shown in (a) which is similar to the condition in sin-flow map (a). In (b), enclaves are wispy and surrounded with filament-like or patchy structure suggesting that chaotic advection homogenise the mafic and felsic magmas to great extent as similar to the condition in sin-flow map (b).

this granite (figure 2). MEs are sub-rounded, elongated or irregular in shape (figure 2a). They are fine-grained equigranular rocks without any phenocryst. Their size varies and most abundant in all the studied outcrops. Two types of MEs such as melanocratic and mesocratic are noticed, and they occur side by side (figure $2 \mathrm{~b}$ ). There are multiple evidences that ME magma had interacted with the host granite. They show sharp to gradational contact with the host granite suggesting liquidliquid interaction and igneous origin. Most of the mesocratic enclaves show wispy tail (figure $2 \mathrm{~b}$ ) or filament-like structure around it (figure 3b), whereas others show magmatic deformation in the form of linear stretching, spindle shape and folding (figure 4b). Melanocratic enclaves characteristically show network of vein-like injection (figures 4a, 5a and b), ptygmatic folding of granitic veins breaking apart of MEs by injection of granite magma (figure 5d). Another unique feature in the host granite is the mesocratic and melanocratic banded structures that are pervasively noticed from all the studied outcrops (figure 6). These wispy bands are made of alternate layers with varying modal proportions of mafic and felsic phases. These banded structures are interpreted to be 

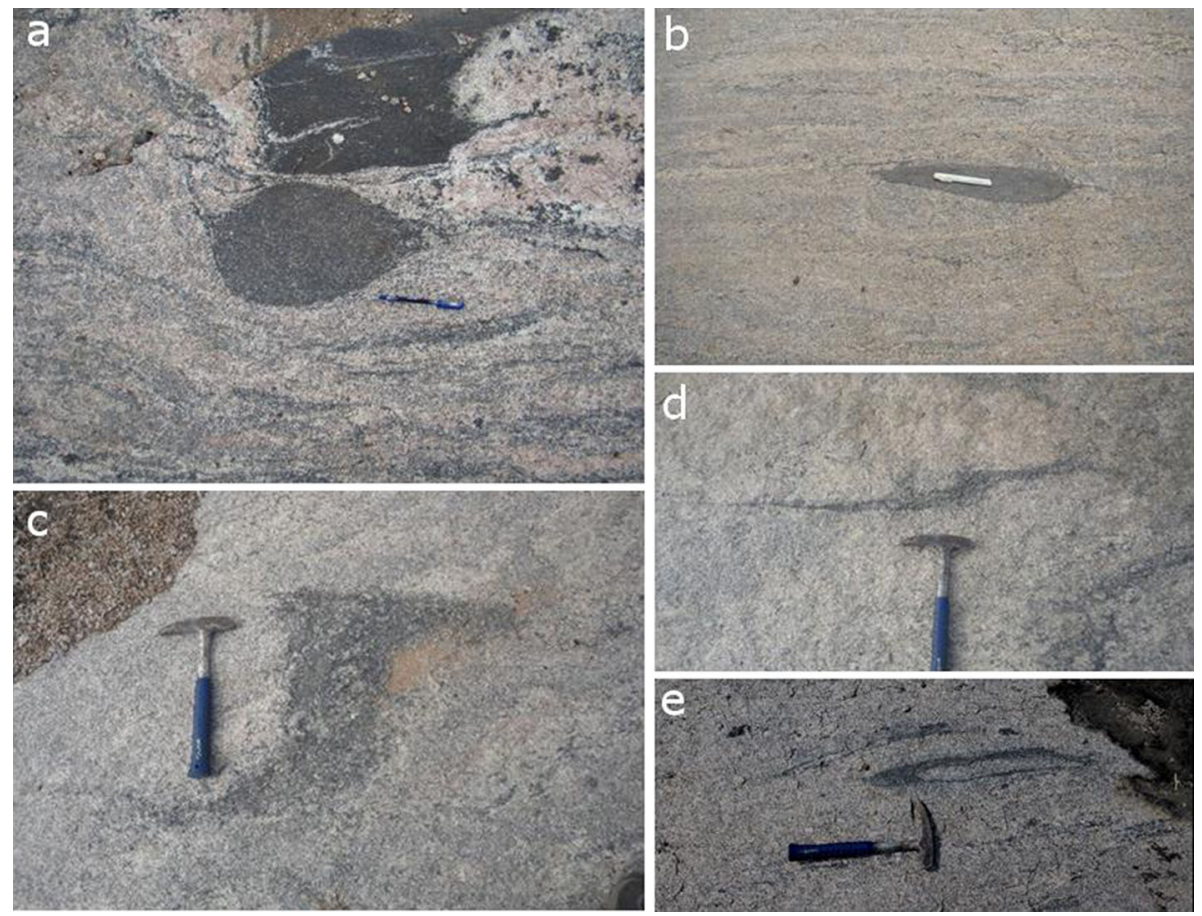

Figure 4. Field photographs showing various stages of magmatic deformation of ME hosted in Nalgonda granite. (a) Melanocratic and mesocratic MEs embedded in the granite with strips of melanocratic bands which are interpreted as flow structure. (b) A spindle-shaped ME in the granite. Notice that longer axis of the ME is parallel to the light and dark banded structures in the host granite. (c) A wispy ME with diffused boundary. It shows partly folded and tapering ends. (d) Linearly deformed ME. (e) Magmatic folding in linearly deformed ME.
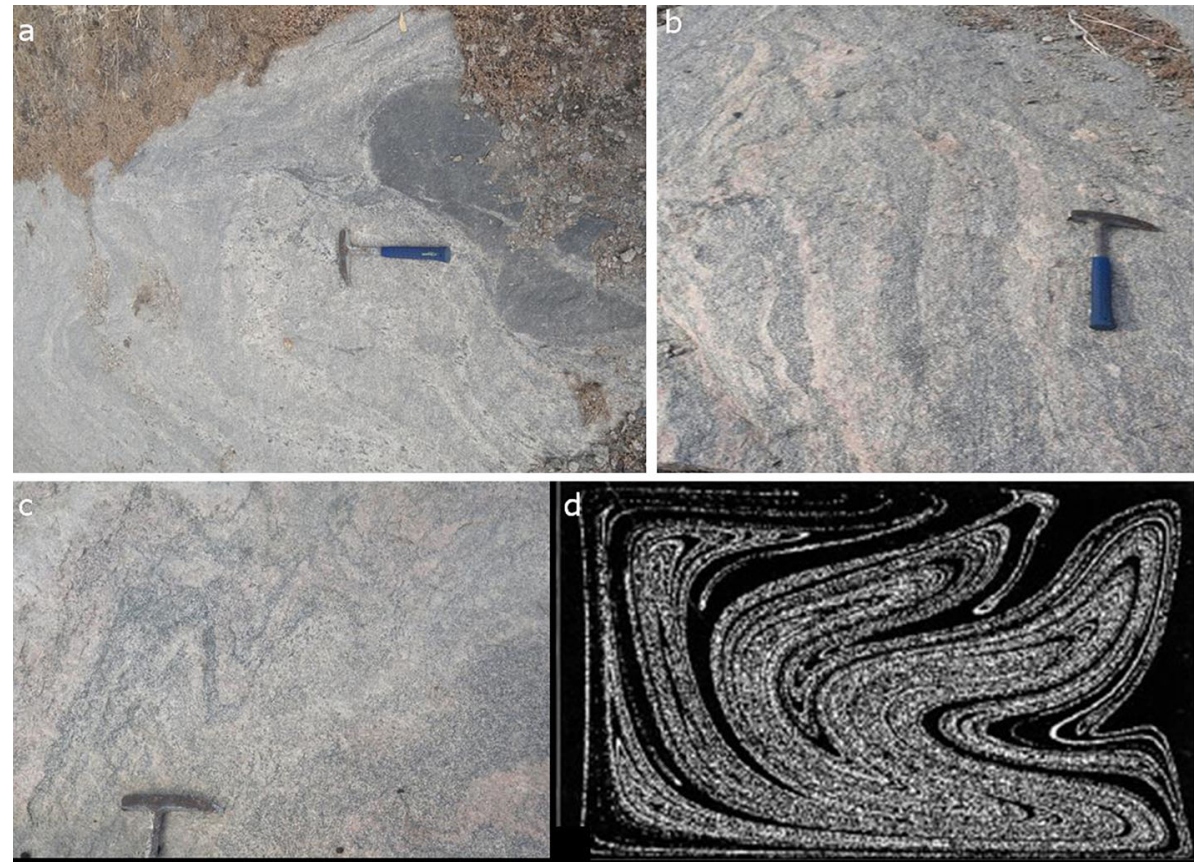

Figure 5. Field photographs showing magma mixing-related flow band structure in Nalgonda granite. (a) An ME surrounded with alternate wispy layers of light and dark bands. (b and c) Alternate layers of wispy light and dark banded structures in the host granite. They show partial folding. Field evidences shown in photographs (a-c) are compared with numerically stimulated mixing structure (d) from Perugini et al. (2003a, 2003b, and references therein). Both show remarkable similarities. 

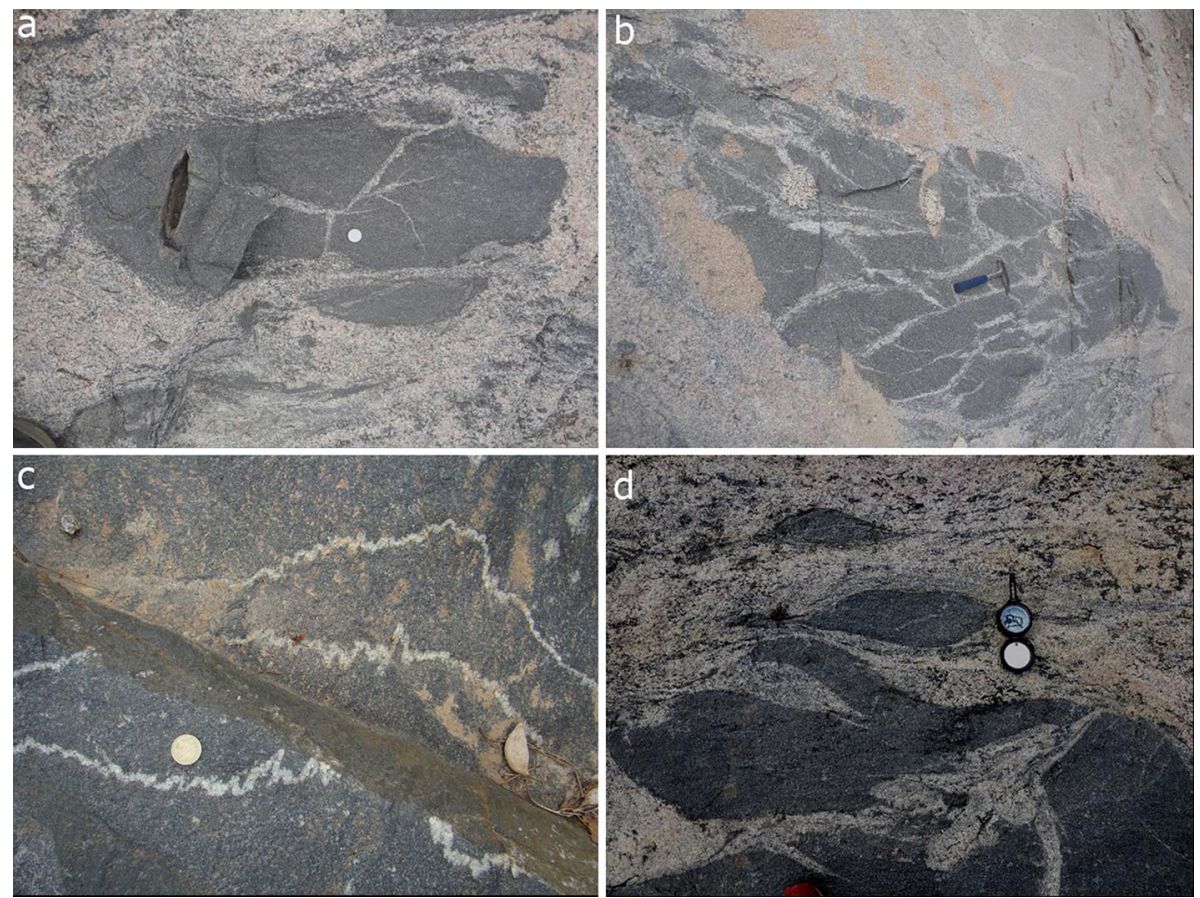

Figure 6. Field photographs. (a) A melanocratic ME showing granitic vein injection and breaking apart into smaller one. Notice the tapering ends of granitic vein indicating direction of vein injection. These veins are from the host granitic magma injecting into the ME. (b) Network of granitic injections in a large-sized ME. (c) Thin granitic veins in ME show crenulation folding. (d) Granitic injection into ME and shows plastic deformation and breaking apart. Notice the smaller spindle-shaped ME.

part of magma flow-related structures. Flow bands are mostly found straight and subparallel, though they show folding and distorted curvy patterns in localised areas of a few metres (figure 6). In general, they have N-S trend in all the studied outcrops. In most of the outcrops, mesocratic MEs are embedded in the granite with banded structure (figure 2). Longer axis of the elongated MEs is parallel to the flow band structures (figures $4 \mathrm{~b}$ and $6 \mathrm{~b}$ ).

\section{Textural relationships}

The host granite is primarily made of inequigranular grains of K-feldspar ( $\sim 36 \%)$, quartz $(\sim 30 \%)$, plagioclase $(\sim 29 \%)$ and biotite $(\sim 5 \%)$ and in general having allotriomorphic to hypidiomorphic texture (figure 7a). Occurrence of euhedral apatite is a unique feature (figure 7b). Feldspars often show sub-solidus recrystallisation developing perthitic and myrmekite textures. K-feldspar encloses plagioclase forming poikilitic texture. Coarse-grained plagioclase occasionally shows dusty appearance (figure 7c). Rapakivi texture is frequently noticed, in which plagioclase is mantled by K-feldspar (figure 7d). Smaller plagioclase exhibits sericitised core and optically clear outer growth zone (figure 7e). Bladed form of biotite grown in the interstitials of large K-feldspars is noticed (figure $7 f$ ).

MEs show distinct petrographic features compared to the host granite. They composed mainly of biotite $(\sim 41 \%)$, followed by plagioclase $(\sim 33 \%)$, quartz $(\sim 16 \%)$, orthoclase $(\sim 10 \%)$ and amphibole $(\sim 5 \%)$. The accessory phases include apatite, titanite, zircon and opaques same as in the host granite. Dimensional preferred orientation of biotite, amphiboles and feldspars is common in most of the MEs and that defines the flow texture (figure 8a). Otherwise, MEs show allotriomorphic or hypidiomorphic texture in general (figure 8c). In some MEs, globules of smaller mafic clots are enclosed as double enclaves, and in such enclaves, biotite forms a rind around it (figure 8f). Amphibole clots are often noticed (figure 8e). Acicular apatite as inclusions in felsic (figure 8d) and mafic phases (figure 8e) is common. The contact between the $\mathrm{ME}$ and granite shows cuspate boundary and sharp change in grain size (figure $8 \mathrm{~b}$ and $\mathrm{f}$ ).

\section{Analytical methods}

Polished thin sections were used for the petrographical description of the rocks and for the 

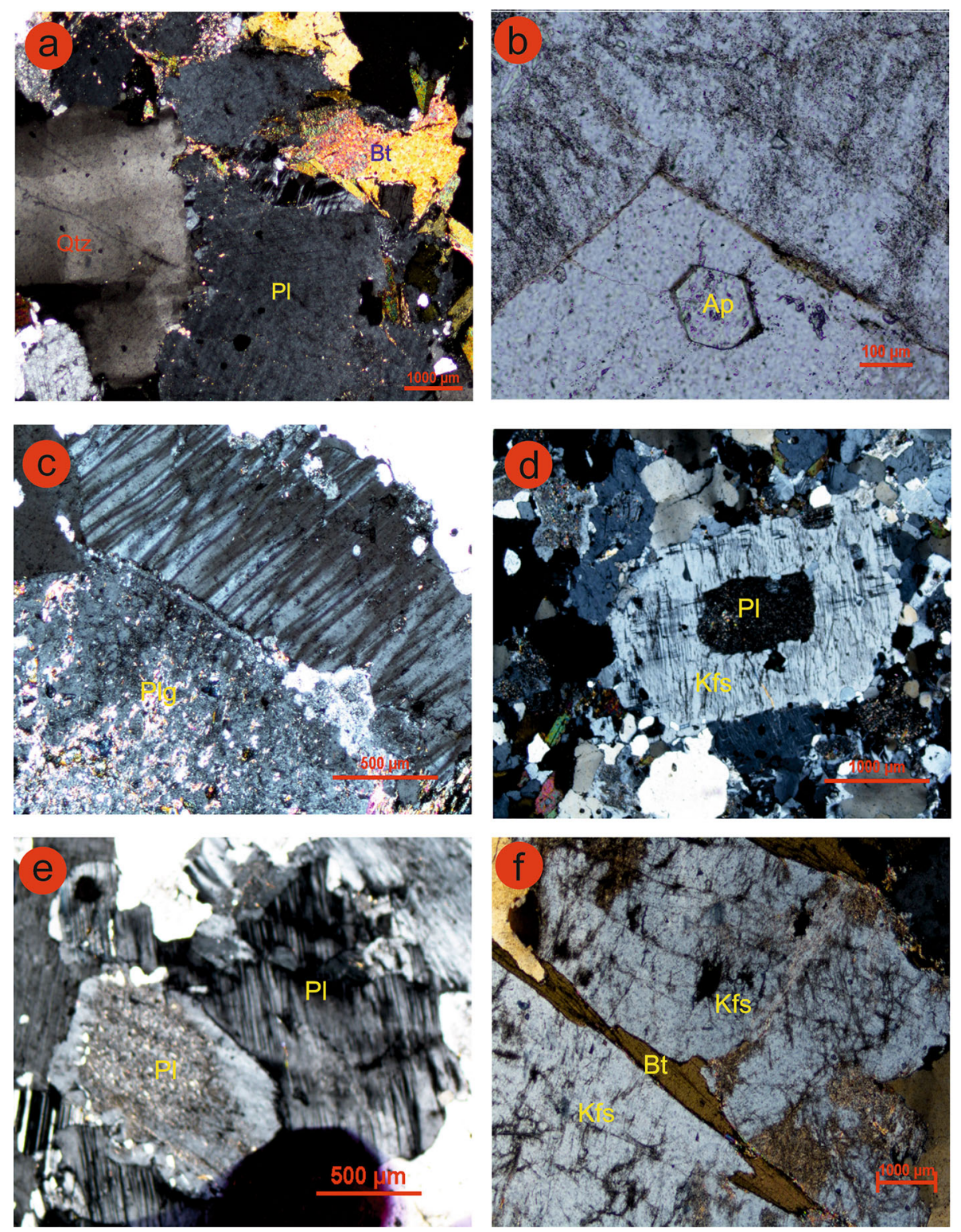

Figure 7. Microphotographs of the host granites: (a) polysynthetic quartz and altered biotite forming the hypidiomorphic texture, (b) euhedral apatite uniquely observed only in the host granite, (c) perthite texture and dusty/spongy plagioclase formed after interaction with calcic melt, (d) K-feldspar forming rim-like structure around plagioclase to form the rapakivi texture, (e) plagioclase showing cellular zoning, along with saussuritisation and (f) bladed biotite grown in between large $\mathrm{K}$-feldspar grains.

microprobe analyses. Mineral chemical analyses were performed on a Cameca SX-100 electron microprobe equipped with wavelength-dispersive spectrometers, using $15 \mathrm{kV}$ acceleration voltage and $20 \mathrm{nA}$ beam current (tables 1 and 2). Standards include a variety of natural minerals and oxides. Whole-rock major oxides and trace elemental compositions of the studied rocks were measured by X-ray fluorescence spectrometry (XRF; Philips MAGIX PRO Model 2440) and highresolution inductively coupled plasma mass spectrometry (HR-ICP-MS; Nu instruments Attom,
UK) instruments, respectively (table 3 ). All the analyses were carried out at CSIR-NGRI, Hyderabad, India.

\section{Results}

\subsection{Mineral chemistry}

The mineral chemistry data of feldspars (table 1) and micas (table 2) from the host, mixed zone (from magma flow) and MEs are presented. 

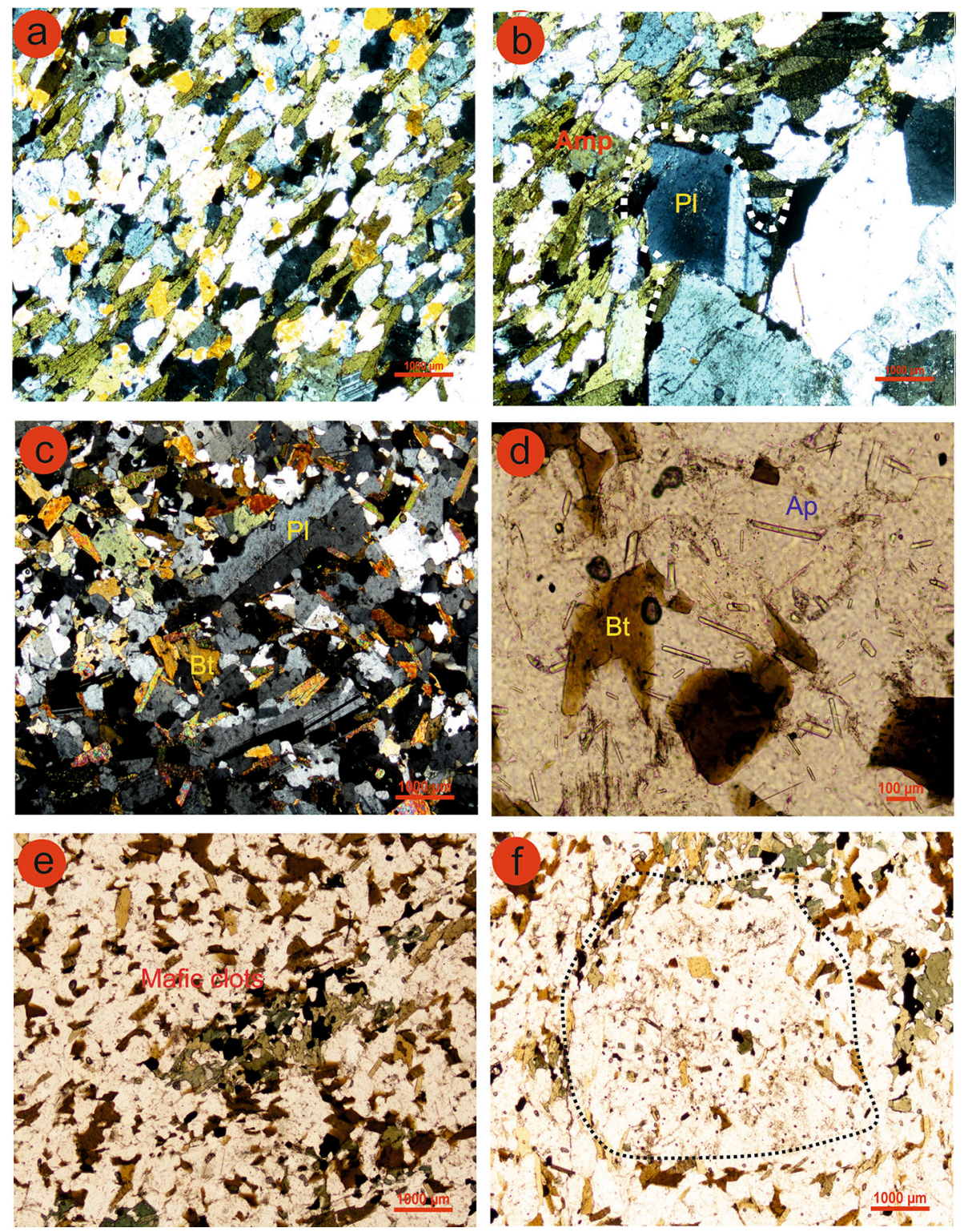

Figure 8. Microphotographs of the MEs: (a) dimensional preferred orientation of mafic minerals in ME, defining the flow texture, (b) contact between the ME and host granite forming cuspate boundary with grain size variation of both components, (c) allotriomorphic texture in $\mathrm{ME},(\mathbf{d})$ acicular apatite formed by quenching, (e) mafic mineral assemblage forming mafic clots and (f) globules of smaller mafic enclaves are enclosed as double enclaves, and biotite forms as rind around the former ME.

\subsubsection{Feldspars}

The plagioclase feldspars from the host granite, mixed zone and the MEs have similar composition confined to oligoclase (table 1 and figure 9). However, there is a minor compositional variation noticed among the rock types for the range of oligoclase composition such as in MEs, the composition is towards the calcic end (average $\mathrm{Ab}_{68}-\mathrm{An}_{26}-\mathrm{Or}_{4}$ ); in the host granite, the composition is towards the sodic end (average $\mathrm{Ab}_{75}-\mathrm{An}_{22}-\mathrm{Or}_{2}$ ), whereas for the plagioclase from the mixed zone (average $\mathrm{Ab}_{53^{-}}$
$\left.\mathrm{An}_{12}-\mathrm{Or}_{33}\right)$, the composition falls in between the sodic and calcic ends of oligoclase (figure 9 ).

\subsubsection{Micas}

Micas from MEs and host granite are of biotite composition (table 2 and figure 10a). The identical

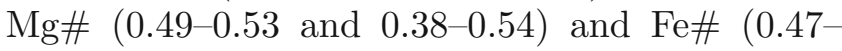
0.51 and $0.46-0.62)$ for the biotites of MEs and host granites (table 2) suggest equal crystallisation temperatures at $\sim 500^{\circ} \mathrm{C}$ (figure 10b; Henry et al. 2005), and such similarity could be due 


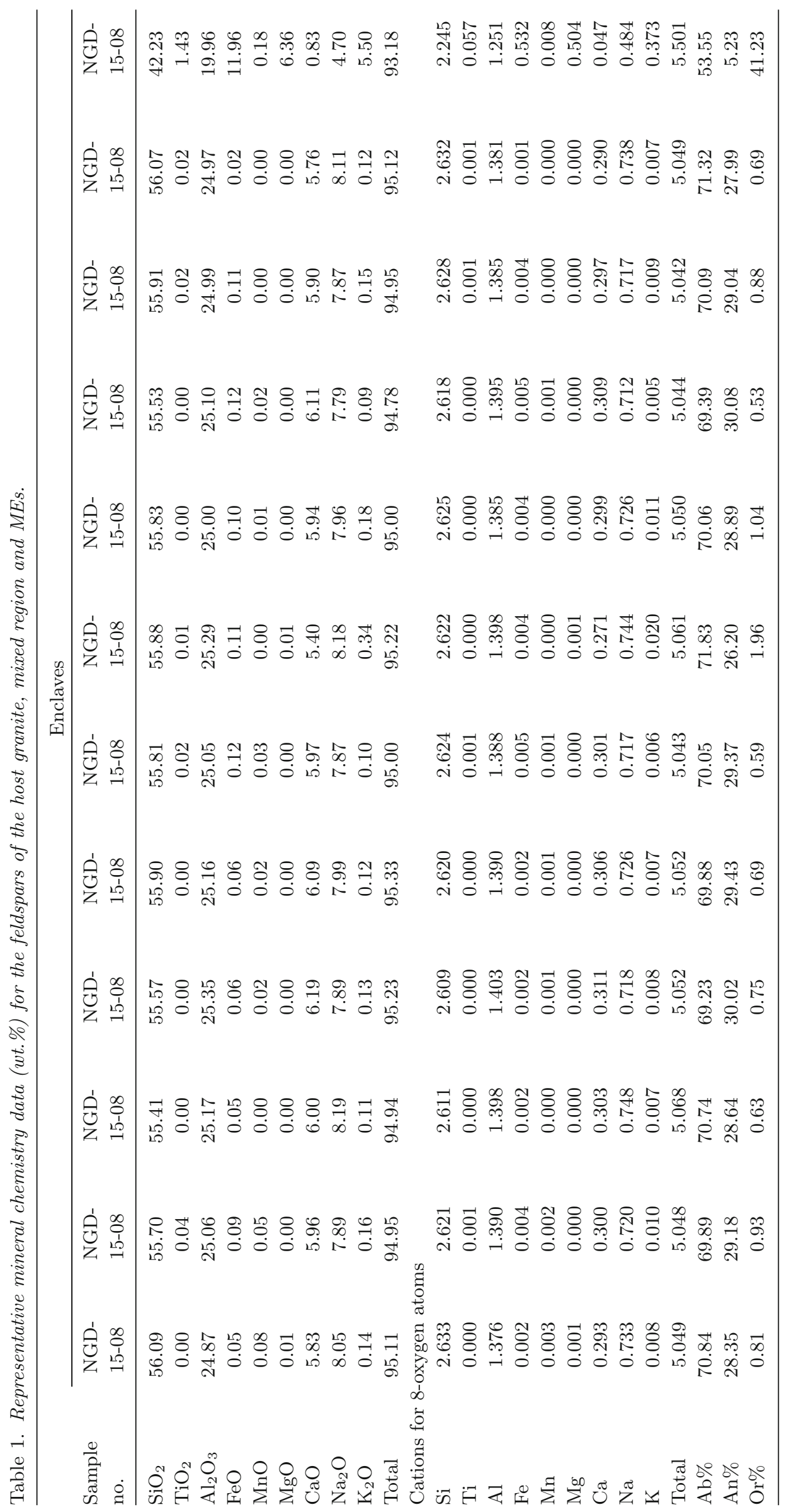




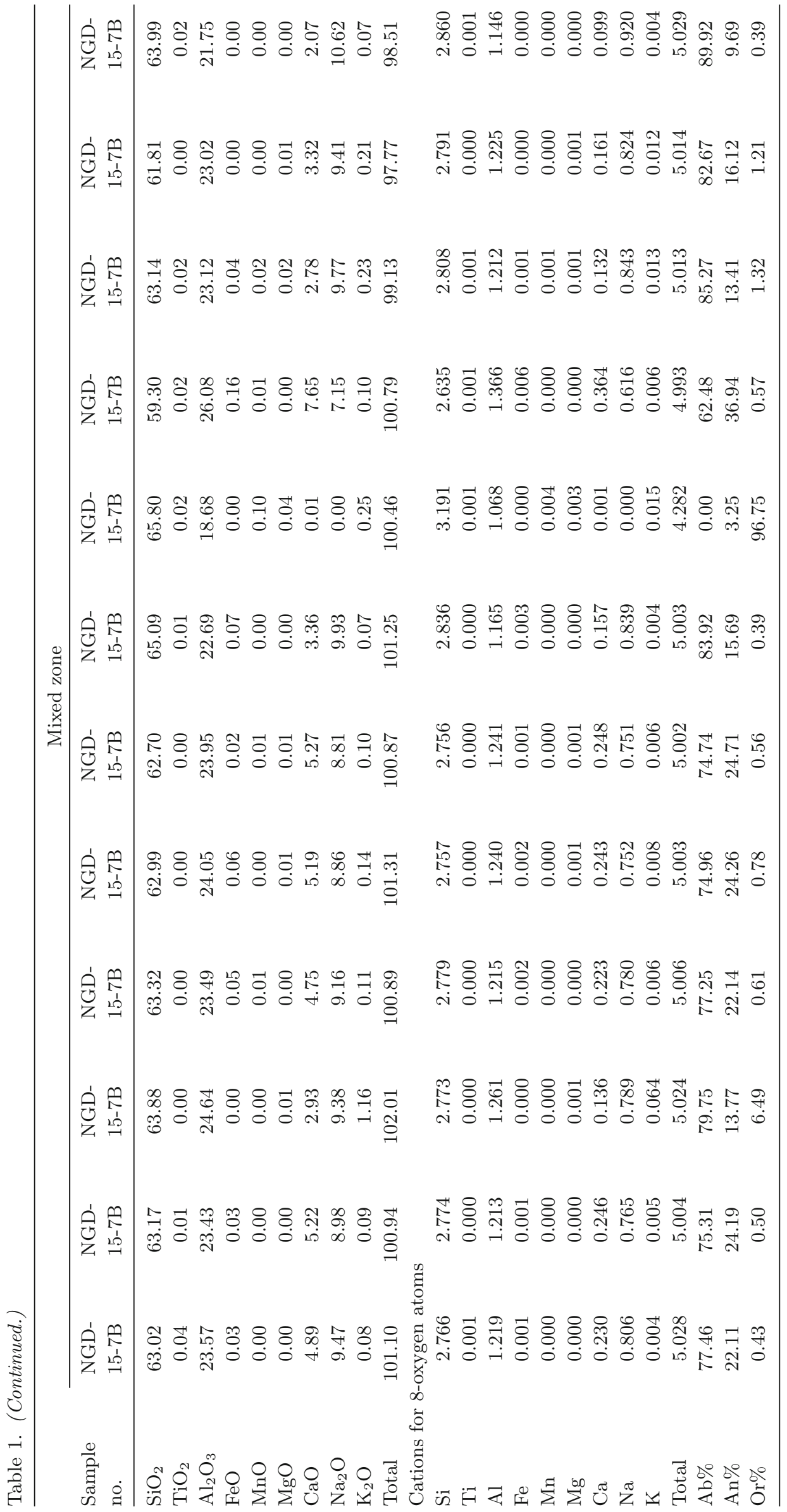




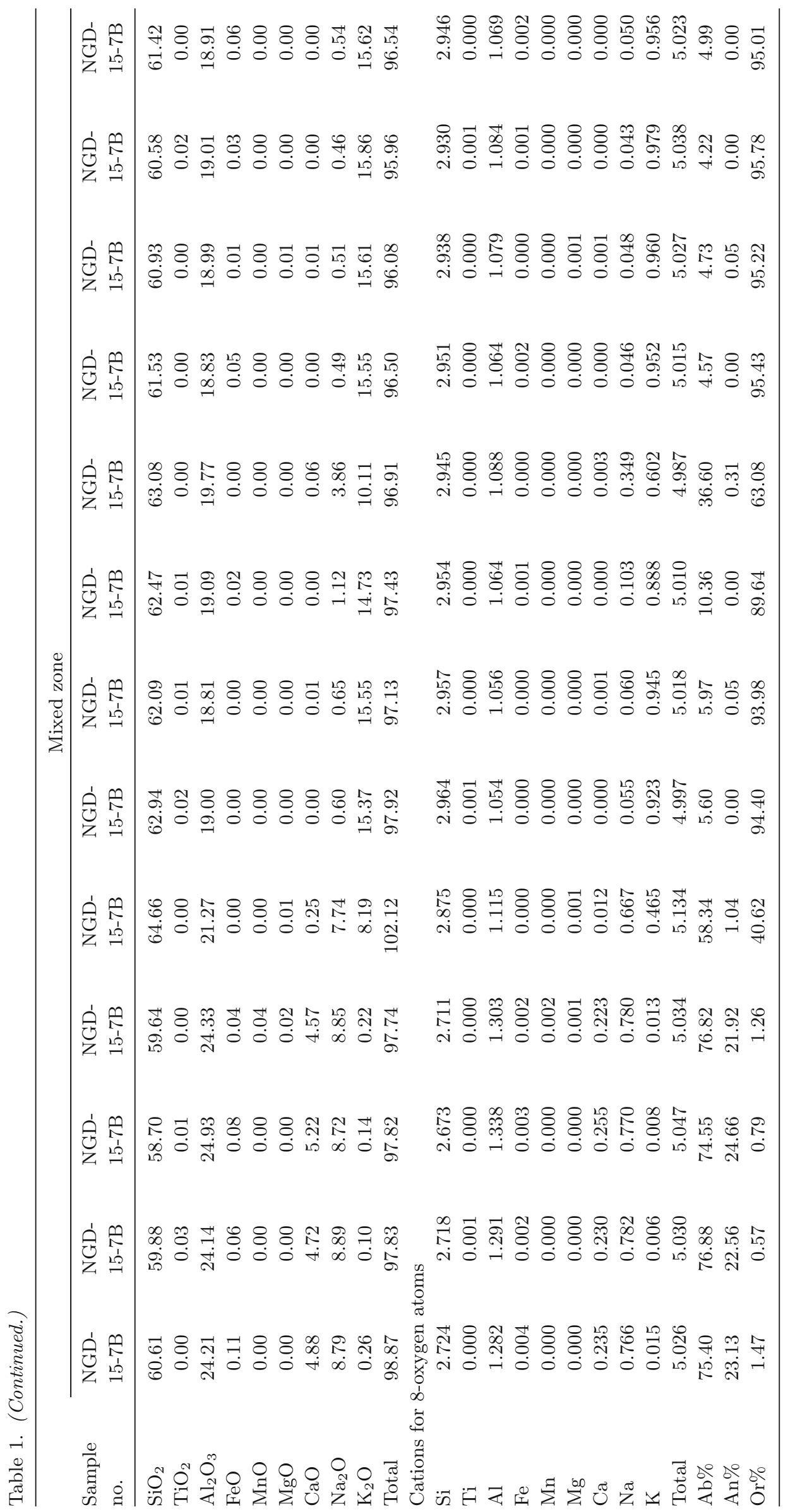




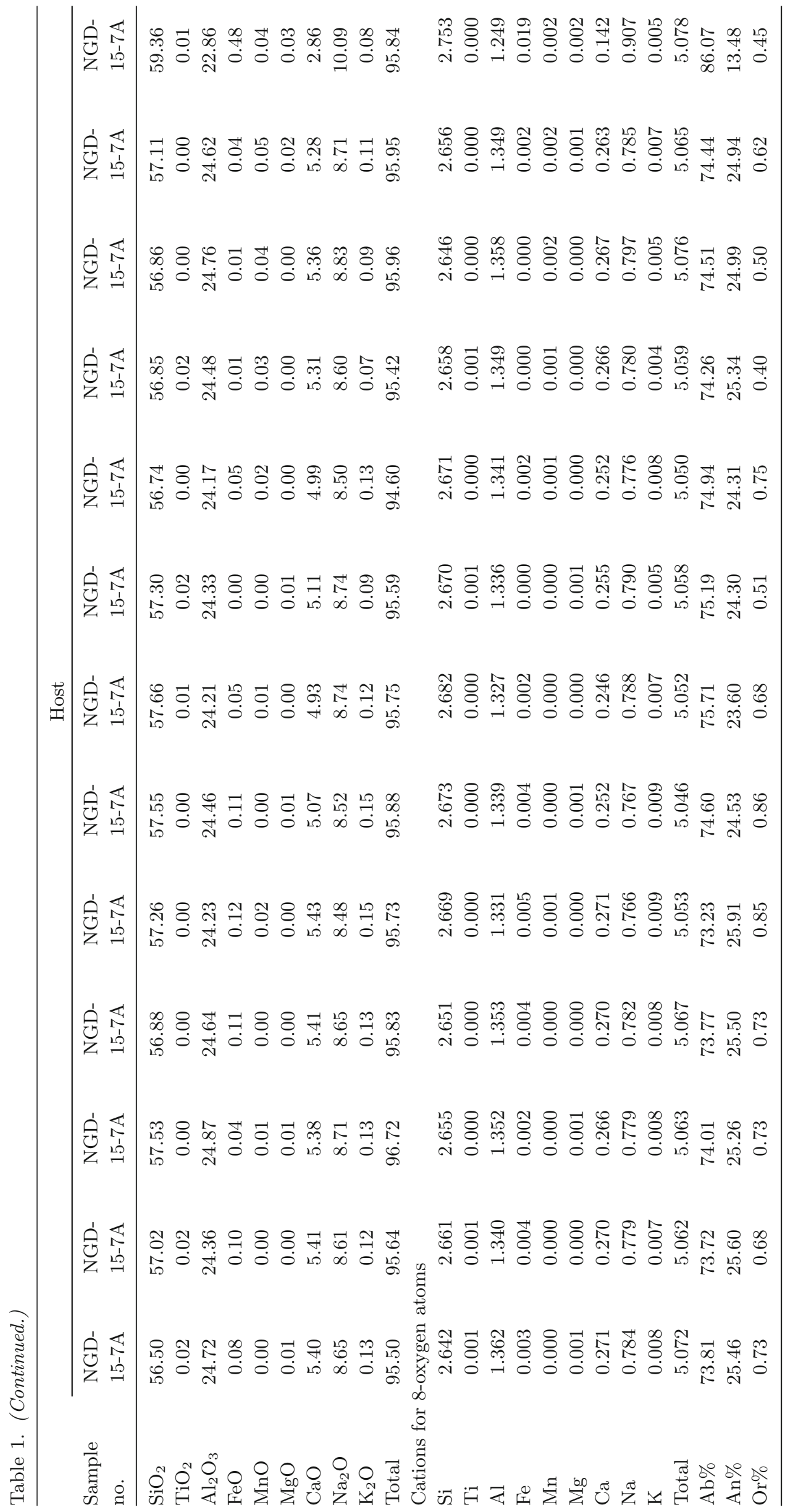




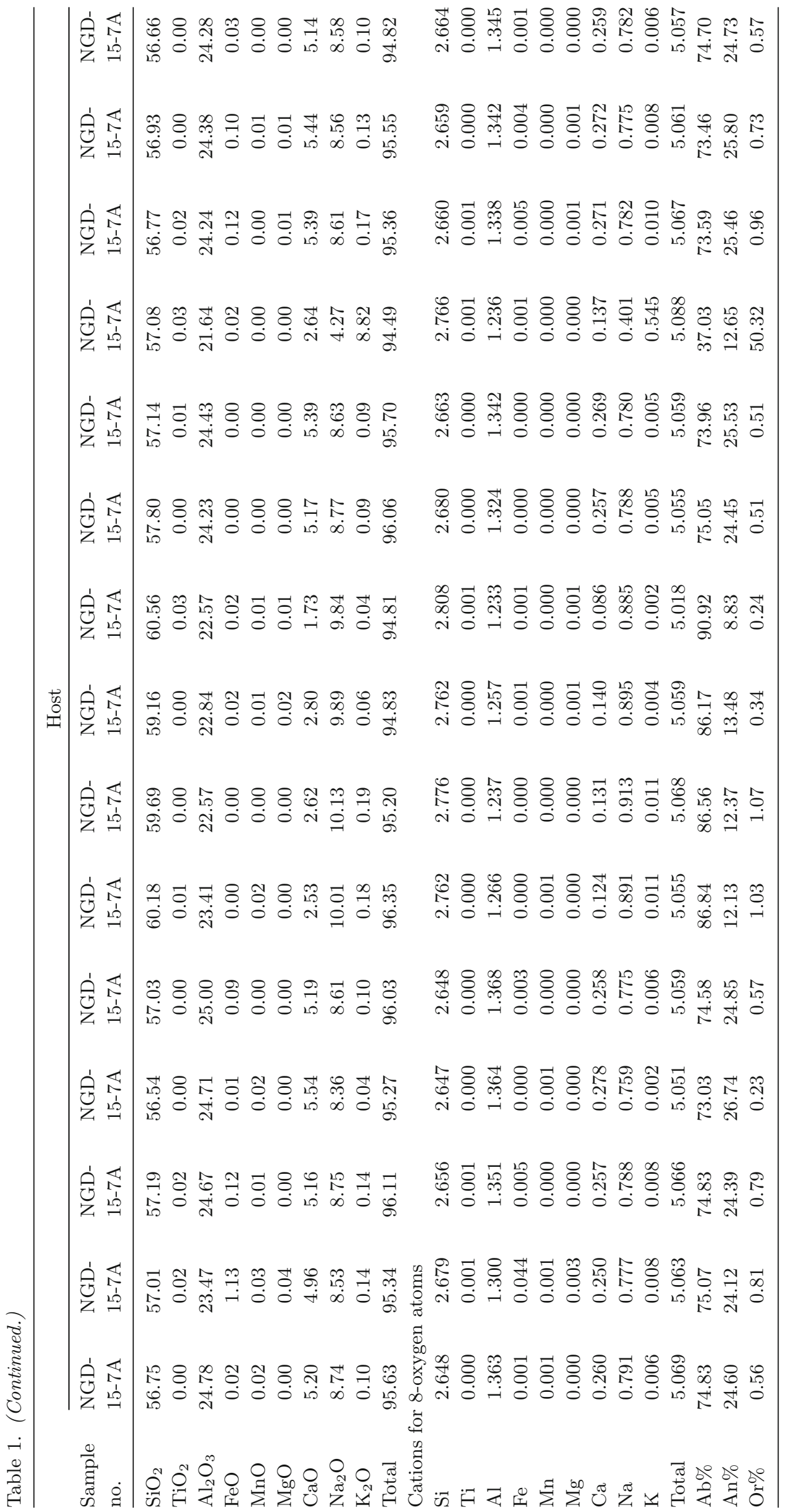









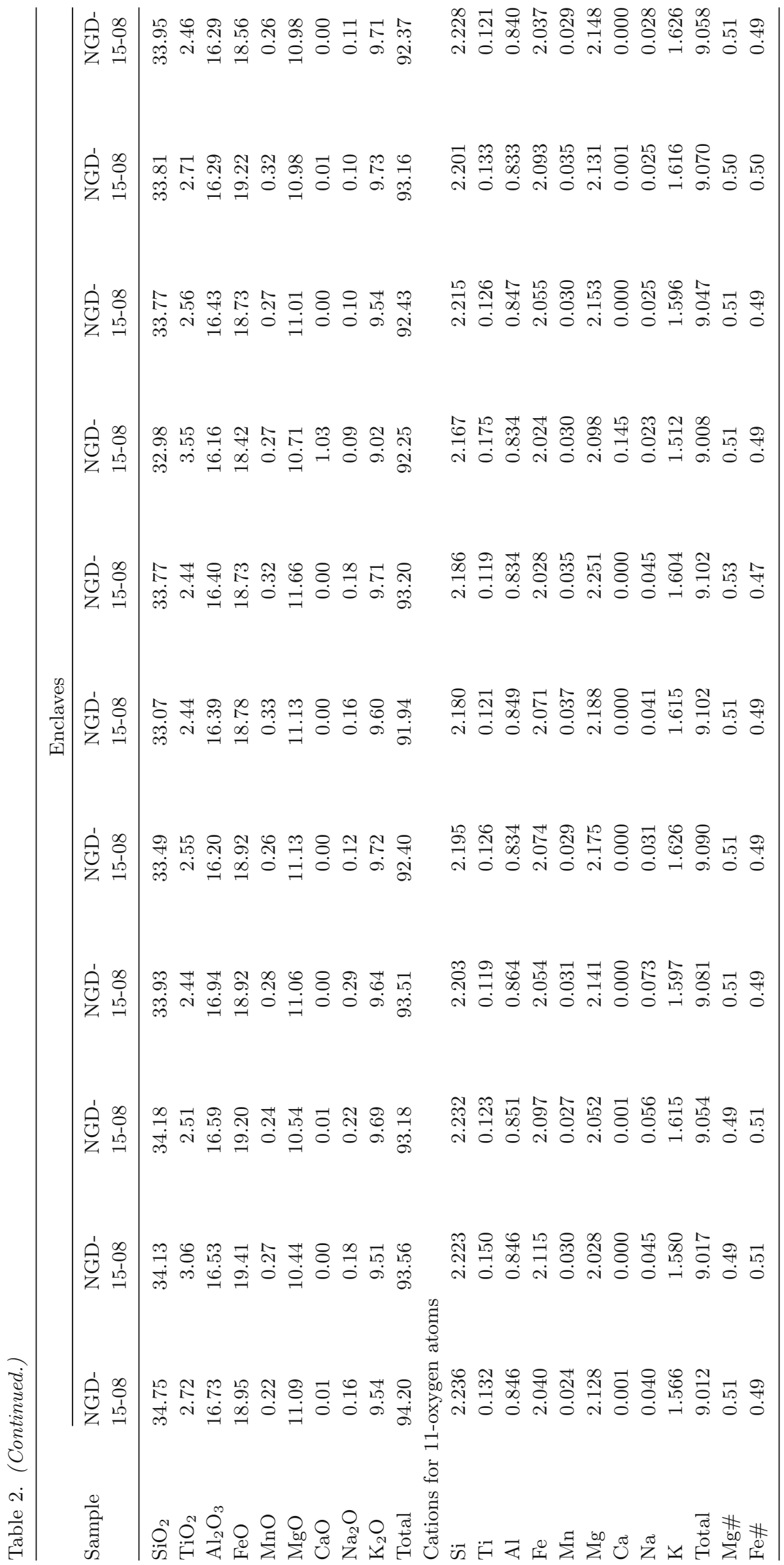


age 16 of 27

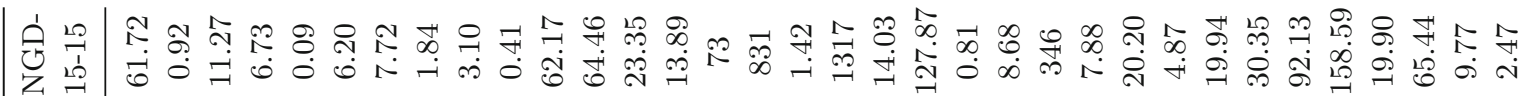

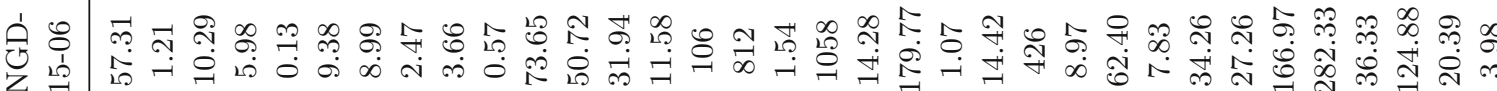

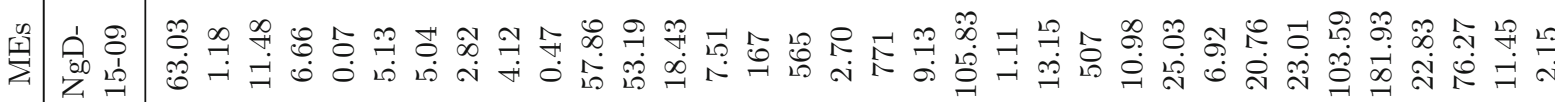

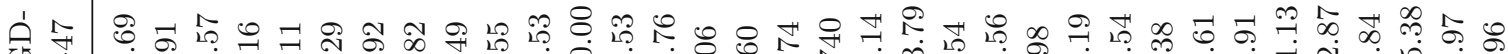
若

궁

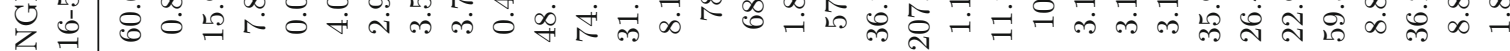

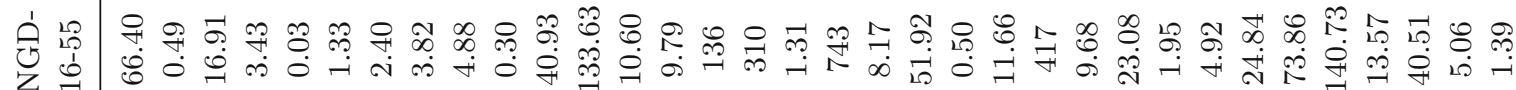
乙

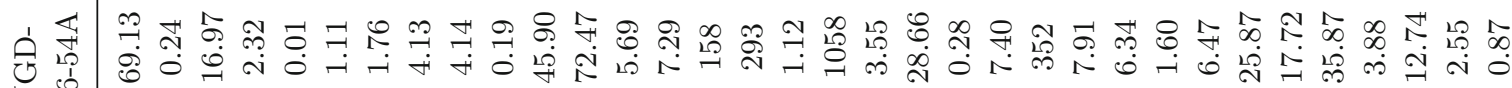
垈

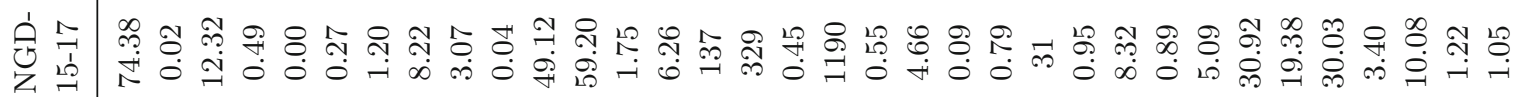
它

ப่우

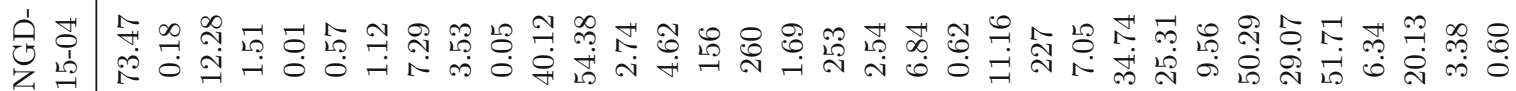

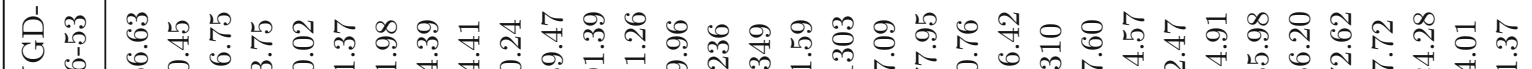
Z

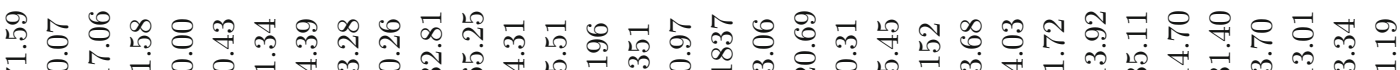
乙

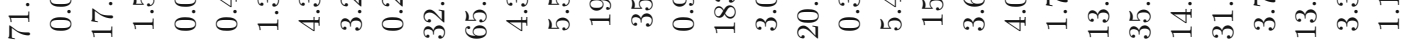

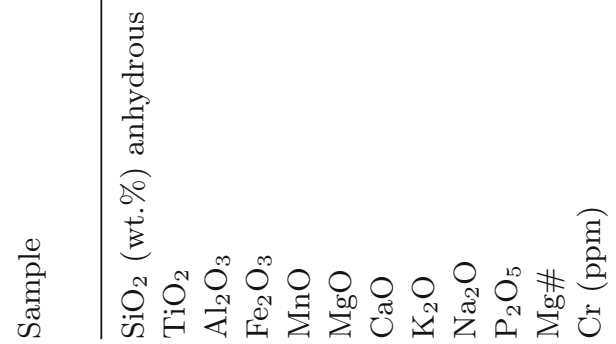

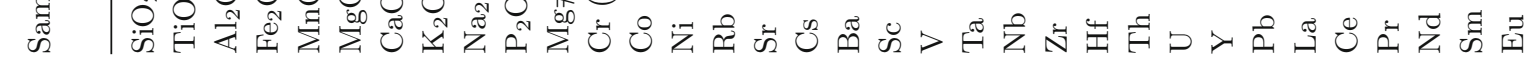




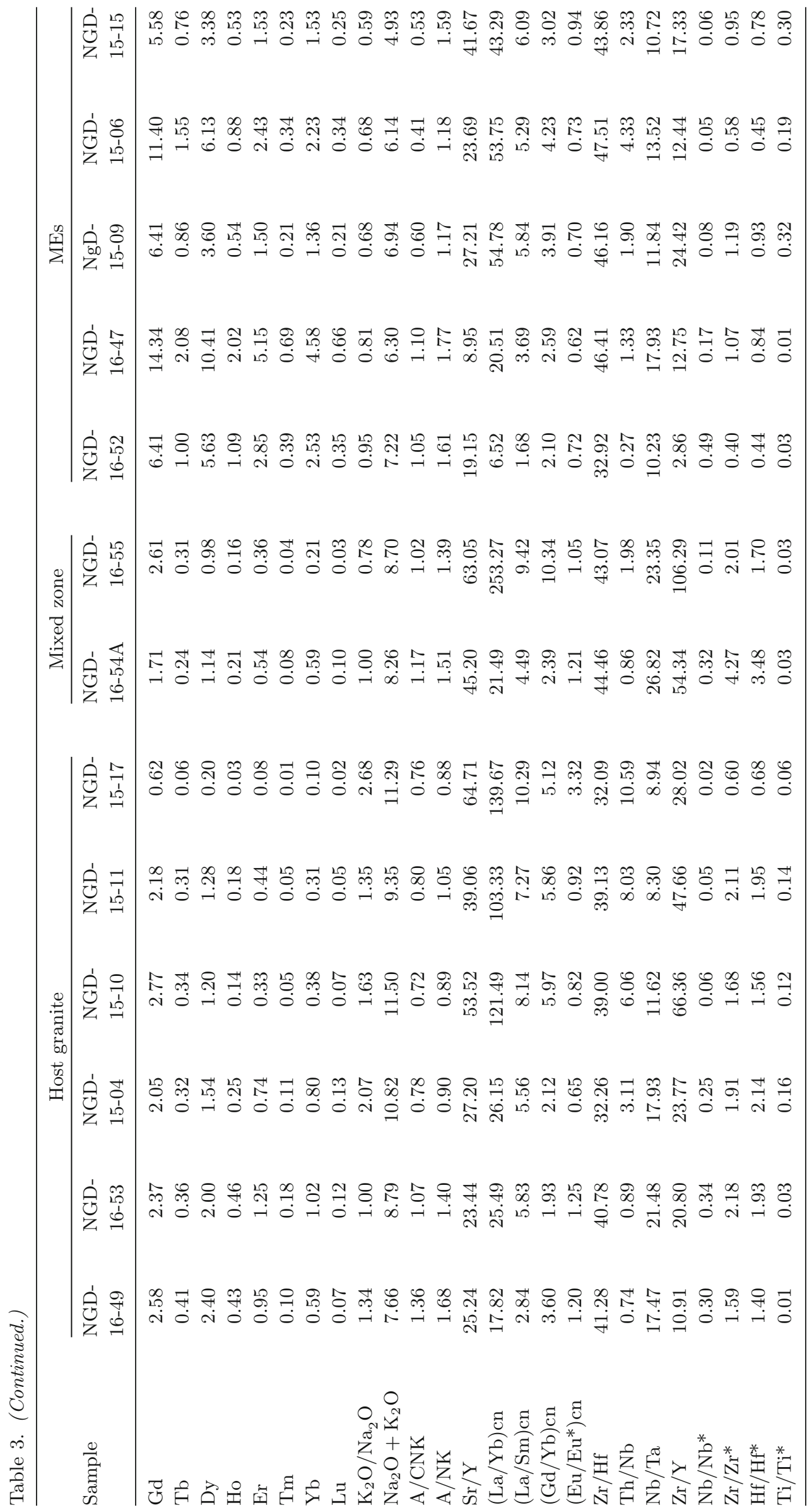




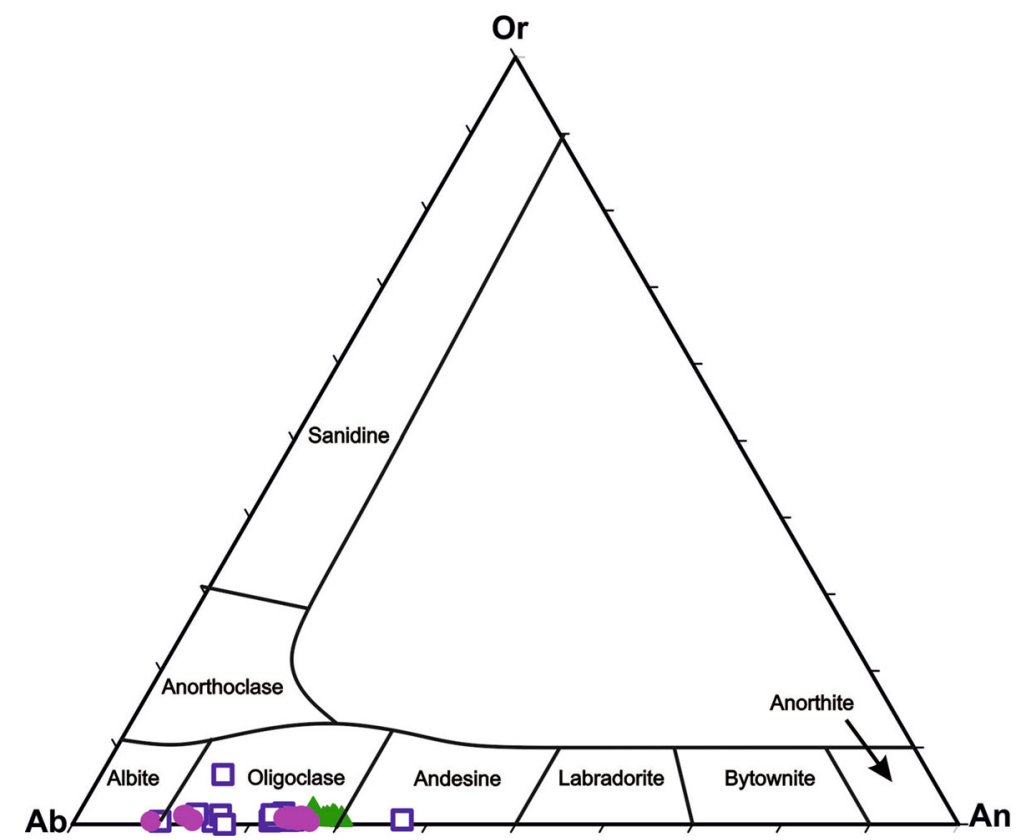

Figure 9. Ab-An-Or diagram showing compositional variations and distribution of feldspar mineral in the host, mixed zone and MEs (after Deer et al. 1992).

to the re-equilibration during the magma mixing and mingling. In the $\mathrm{MgO}-\mathrm{FeO}-\mathrm{Al}_{2} \mathrm{O}_{3}$ ternary discrimination diagram of Abdel-Rahman (1994), these biotites are confined to the calc-alkaline field (figure 11).

\subsection{Geochemistry}

The $\mathrm{SiO}_{2}$ content distinguishes rock types, highest being in the host granites (66.63-74.38 wt.\%), lowest among the MEs (57.31-63.03 wt.\%) and the mixed zone lying in between (66.40-69.13 wt.\%; table 3 ). In the total alkalis vs. silica diagram (Le Maitre 1984), the host granites are confined to the field of granite with the alkalis ranging between 7.66 and 11.50 wt.\%, the mixed zone rocks are into the field of quartz monzonite with the composition of alkalis ranged between 8.26 and 8.70 wt.\%. The MEs are distributed into the fields of monzonite, monzodiorite and diorite (figure 12a) with the alkalis ranged between 4.93 and 7.22 wt.\%. In the alumina saturation index diagram (Shand 1947), these rocks exhibit varied distribution between the metaluminous and peraluminous fields (figure 12b). Similar variation is noted among other major elemental systematics (figure 13), with the $\mathrm{TiO}_{2}(0.02-0.49$ wt. $\%$ and $0.88-1.21$ wt.\%), $\mathrm{Fe}_{2} \mathrm{O}_{3}(0.49-3.75$ wt. $\%$ and $5.98-9.16$ wt. $\%), \mathrm{MgO}$ (0.27-1.37 wt.\% and 4.08-9.38 wt.\%), respectively, for the host granite and MEs (table 3), illustrating the mixing of two end-member components. The potassic nature of the host granites is represented by $\mathrm{Na}_{2} \mathrm{O} / \mathrm{K}_{2} \mathrm{O}$ ratios of $<1$ (average 0.76 ), and the MEs have higher $\mathrm{Na}_{2} \mathrm{O} / \mathrm{K}_{2} \mathrm{O}$ ratios of $>1$ (average 1.38; table 3 ). This observation is corroborated by variability in the mineral proportions among the host and MEs with higher K-feldspar abundance in the former case. Compositional variation is also observed in trace element content, with Rb (115318 and $73-167 \mathrm{ppm}), \mathrm{Ba}(252-1836$ and $570-2740$ ppm), Sr (110-510 and 560-831 ppm), Nb (0.7927 and 8-27 ppm) and Zr (30-416 and 103-798 ppm) for the host granite and MEs, respectively (table 3). The chondrite normalised rare earth element (REE) plot (Sun and McDonough 1989) shows the fractionated pattern with light rare earth element (LREE) enrichment, near flat heavy rare earth element (HREE) signatures and slight negative $\mathrm{Eu}$ anomalies; however, variability is noted in the total REE content between the three magmatic components (figure 14a), with the total REE ranging from 61 to 290 and 151 to 677 for the host granite and MEs, respectively (table 3 ). The primitive mantle normalised multi-elemental variation diagram (Sun and McDonough 1989) illustrates the large-ion lithophile element (LILE) enrichment and high-field strength element (HFSE) depletions with characteristic negative anomalies of $\mathrm{Nb}$ and Ti (figure 14b). 

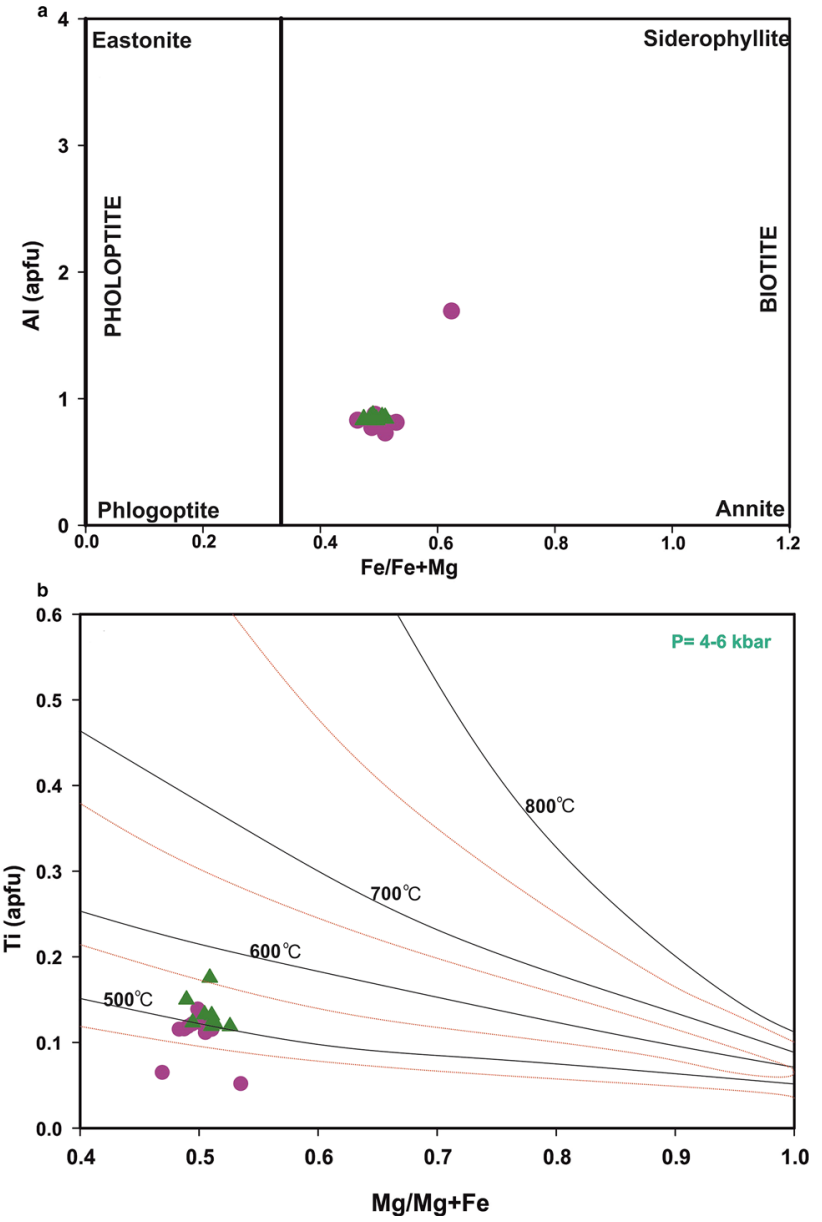

Figure 10. (a) $\mathrm{Al}$ (a.p.f.u.) vs. $\mathrm{Fe} / \mathrm{Fe}+\mathrm{Mg}$ diagram showing biotite composition of the micas in the host and MEs (after Nachit et al. 2005) and (b) Ti (a.p.f.u.) vs. $\mathrm{Mg} / \mathrm{Mg}+\mathrm{Fe}$ showing differences in crystallisation temperature of biotites in the host and MEs (after Henry et al. 2005).

\section{Discussion}

\subsection{Felsic-mafic magma interaction: Evidences from outcrop-scale structures and micro-textures}

Magma mixing and mingling play a key role in generating the compositional diversity in granitoids, particularly mixing with mafic magma (Vernon 1984, 1990; Wiebe et al. 1997; Kumar et al. 2004; Yang et al. 2006; Kumar 2010; Jayananda et al. 2014). During mixing process, the degree of homogenisation between the end-members, i.e., felsic and mafic magmas, mainly depends on the degree of crystallisation, viscosity and composition of both interacting magmas (Vigneresse 2015). Field evidences like thoroughly mixed hybrid rock, $\mathrm{ME}$ and synplutonic dykes represent such variations in degree of homogenisation between the interacted magmas (Barbarin 2005; Renjith et al. 2014; Elangovan et al. 2017). In this study area, granites carry abundant ME (figure 2) and show flow band structures (figure 6); both these features are interpreted to be as a result of interaction between felsic and mafic magmas. MEs represent portions of mafic magma that had interacted with felsic magma. Probably, mafic magma must have introduced into the felsic chambers by dyke intrusion or sill-like layers at the bottom of the chamber. Subsequently, they disaggregated into smaller magma globules and disperse throughout the pluton by convection operated in the felsic

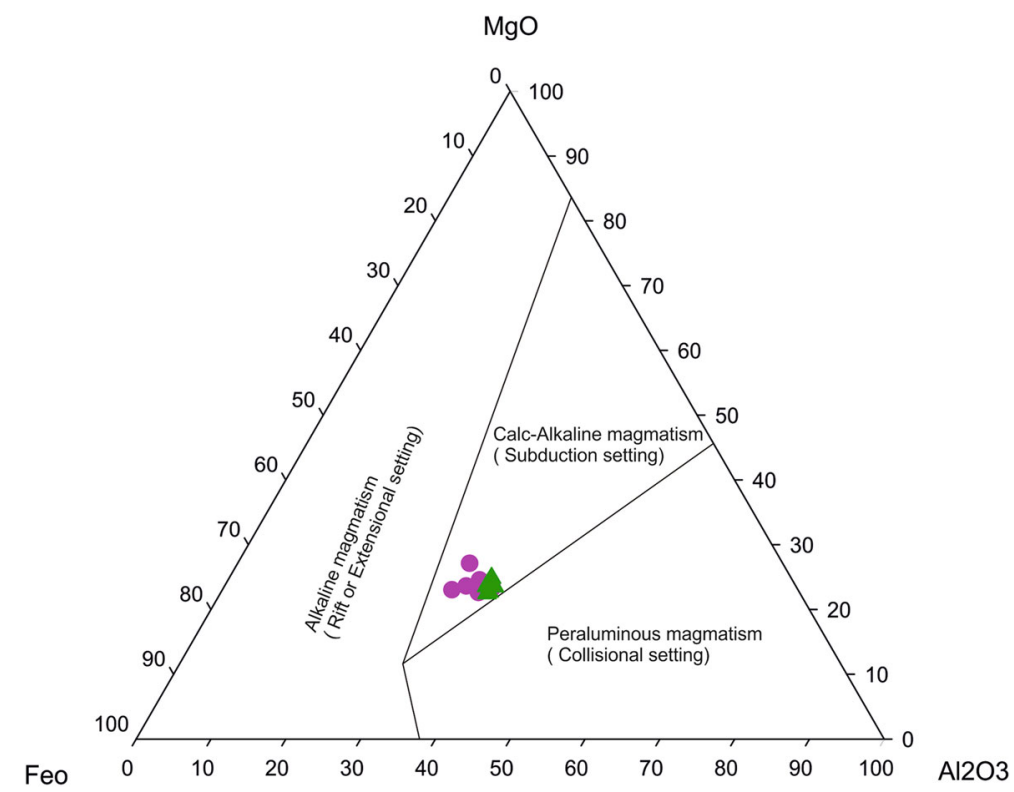

Figure 11. $\mathrm{MgO}-\mathrm{FeO}-\mathrm{Al}_{2} \mathrm{O}_{3}$ discrimination diagram (after Abdel-Rahman 1994) shows biotites from the ME are formed within the calc-alkaline magmatism. 

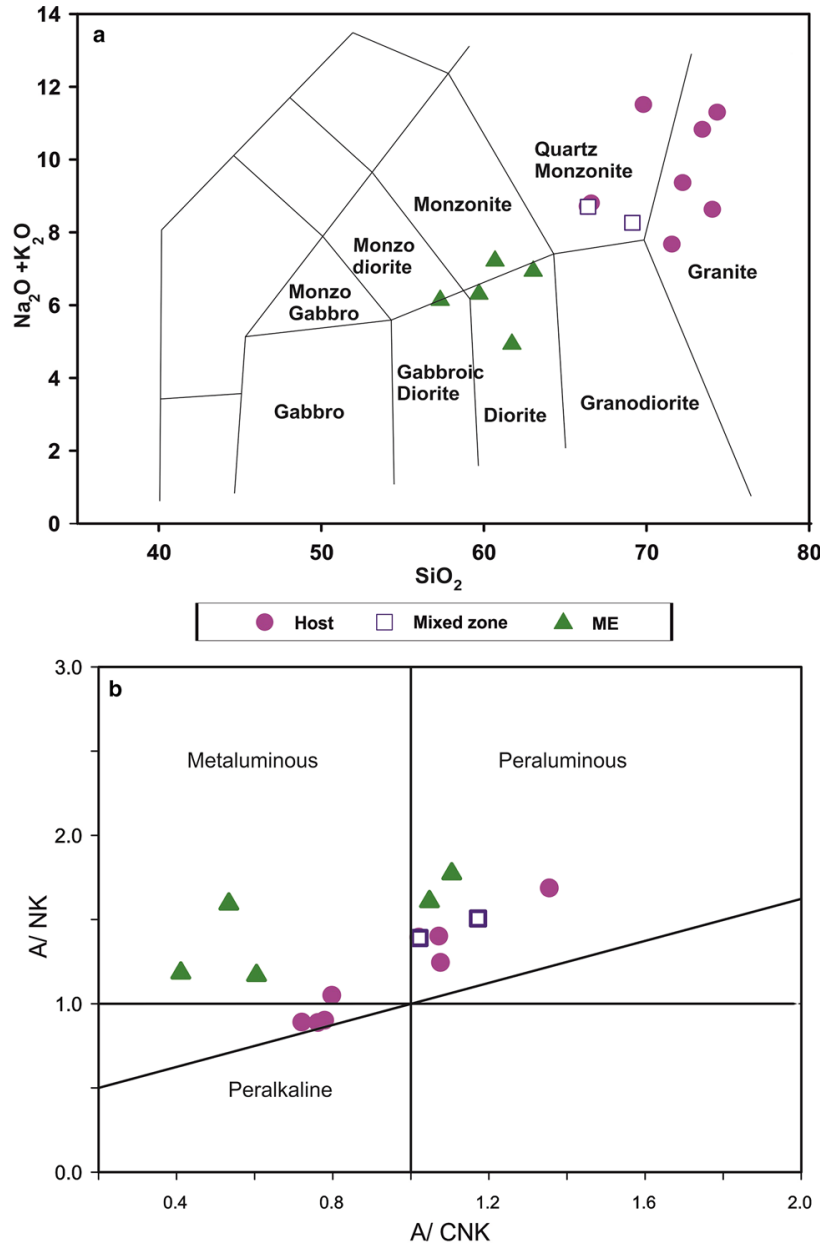

Figure 12. (a) Total alkali $\left(\mathrm{Na}_{2} \mathrm{O}+\mathrm{K}_{2} \mathrm{O}\right.$ wt.\%) vs. $\mathrm{SiO}_{2}$ diagram (Le Maitre 1984), wherein the host granite samples are in the field of granite, the mixed zone samples are into the quartz monzonite field and the MEs are dioritic to monzonitic, and (b) alumina saturation index diagram (after Shand 1947).

chamber (figure 2a). When the hotter mafic magma was initially introduced into the relatively cooled felsic chamber, the mafic magma had subjected to certain degree of thermal quenching as evidenced from their fine-grained nature (figure 8a), acicular apatite (figure 8e) and elongated biotite (figure 7f; Ade-Hall et al. 1971). Even after the initial thermal equilibration with felsic magma by undercooling, the mafic magma was in more melt supported liquid state and was able to interact efficiently with the felsic magma. The MEs that occur in Nalgonda granites can be grouped into two categories: (i) melanocratic and (ii) mesocratic MEs (figures $2 \mathrm{a}$ and $4 \mathrm{a}$ ). Both of them have distinct field and petrographic features indicating that two major episodes of mafic magma mixing had occurred in the Nalgonda granite.
The early mixing event produced mesocratic MEs which show high degree of homogenisation with the host granite compared to the second stage of mixing event in which mafic magma did not get efficiently mixed and retained almost their physical entity (visual estimate as per field observation). At the early stage of mixing, viscosity contrast between the felsic and mafic magmas was low and hence able to mix efficiently. In mesocratic ME, evidences like wispy tails (figure 6) and cuspate margin (figure 6) strongly support the existence of mafic and felsic magmas of liquidliquid state (Barbarin and Didier 1992; Barbarin 2005), and their gradational contact clearly indicates chemical exchange and interaction. We infer that their mesocratic nature is probably due to the chemical interaction with the host granitic magma as evidenced from the high modal proportions of felsic minerals in mesocratic enclaves than in melanocratic MEs. We also infer that this chemical diffusion was enhanced by the chaotic processes in which the interacting fluids undergo stretching and folding dynamics (Flinders and Clemens 1996; Perugini and Poli 2000; Perugini et al. 2002, 2003a,b). Wispy contact/tail and filament-like mafic bands surrounding the mesocratic ME (figure 3) strongly indicate that chaotic advection (stretching and folding) played a major role in diluting the mafic enclave magma in felsic magma (see explanation in figure 3 ). In all the studied outcrops, evidences of chaotic advection were well preserved particularly in the form of wispy banded structures (figure $6 \mathrm{a}-\mathrm{c}$ ). These structures show remarkable similarity with the numerically simulated mixing patterns shown in (Perugini et al. 2003a, b; figure 6d) and confirm the widespread chaotic mixing processes in the Nalgonda granite.

At a certain period of time in the early stage of mixing, the felsic and mafic magmas had efficiently homogenised, and both of their physico-chemical entity was completely destroyed to generate a new mixed magma. In such thorough mixing conditions, the pre-existing crystals get dissolved by the newly introduced hotter and compositionally distinct mafic magma. When thermal equilibration is regained at the crystal-melt interface, they started to grow again with compositionally distinct outer growth zones. The rapakivi texture (figure $7 \mathrm{~d}$ ) in the host granite reveals that such mixing condition was prevailed during the early crystallisation stage of granite magma (e.g., Hibbard 1981). The margin of core plagioclase in rapakivi texture (figure $7 \mathrm{~d}$ ) 

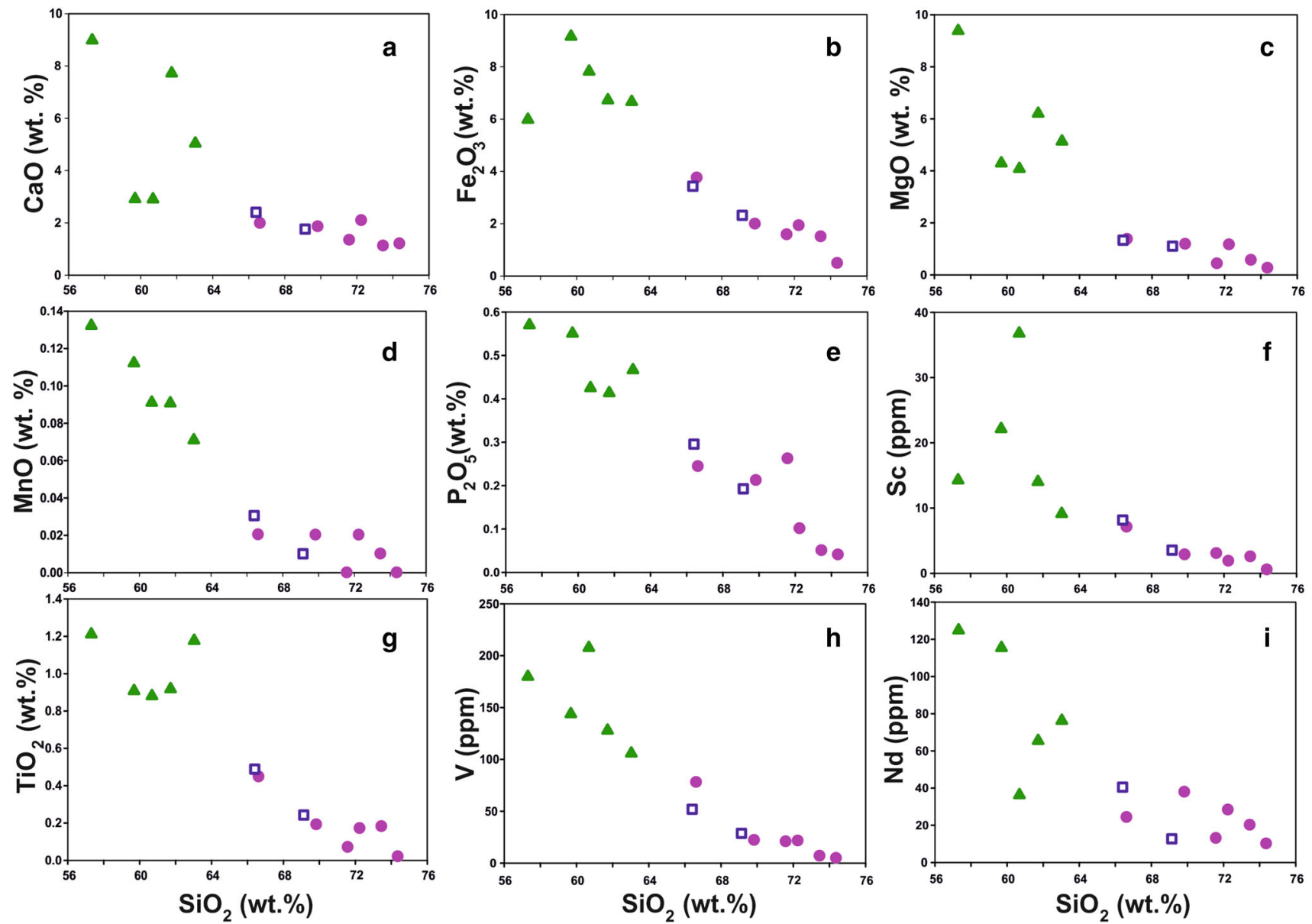

Figure 13. Harker diagrams with coherent linear trend of major and trace elements to demonstrate the mixing between the host granite and ME.

is sub-rounded indicating that dissolution occurred along the corners of pre-existed euhedral grain; meanwhile, their K-feldspar mantle with euhedral outer margin indicates that overgrowth occurred from a compositionally distinct magma with stable magmatic environment in which equilibrium at crystal-melt interface prevailed during crystallisation. Meanwhile, the textures such as cellular zoning (figure 7e) and dusty/spongy textures (figure 7e) in the host granite (e.g., Reid et al. 1983; Hibbard 1991; Baxter and Feely 2002) indicate that undercooling occurred during this early stage of mixing and resulted in these textures.

Mesocratic MEs characteristically show that they are associated with flow band structures in the host granites (figures $4 \mathrm{a}$ and $6 \mathrm{a}-\mathrm{c}$ ). The flow band structure occurs in all the studied outcrops for about $20-\mathrm{km}$-wide zone, and it is worth noting that in all the outcrops, they have similar N-S trend suggesting that convection-related magma flow was operated on magma chamber scale. Evidences also indicate that convection magma flow played a vital role in dispersing the mafic magma globules into various parts of the magma chamber. The longer axis of the large and small MEs is parallel to this flow band structure in the host granite (figures $4 \mathrm{~b}$ and $6 \mathrm{~b}$ ). Meanwhile, it is also noticed from the micro-textures that alignment of elongated minerals in the ME is subparallel with the flow structures in the host granite (figure 8a). These evidences strongly support that ME magma had flown and magmatically deformed along with convection flow operated in the host felsic magma. MEs of linearly stretched (figure 8a) and spindle in shape (figure 8b) also clearly support this inference. From the globular form, the enclaves became linear thin schlieren-like form. Systematic sequences of such magmatic deformation are well preserved in the outcrops of Nalgonda granite as some of the examples are portrayed in figure 4 . This mechanical dilution along with convection-related magma flow was also an effective process in homogenising the enclave magma. In turn, we infer that mechanical dilution along with the magma flow was the main 


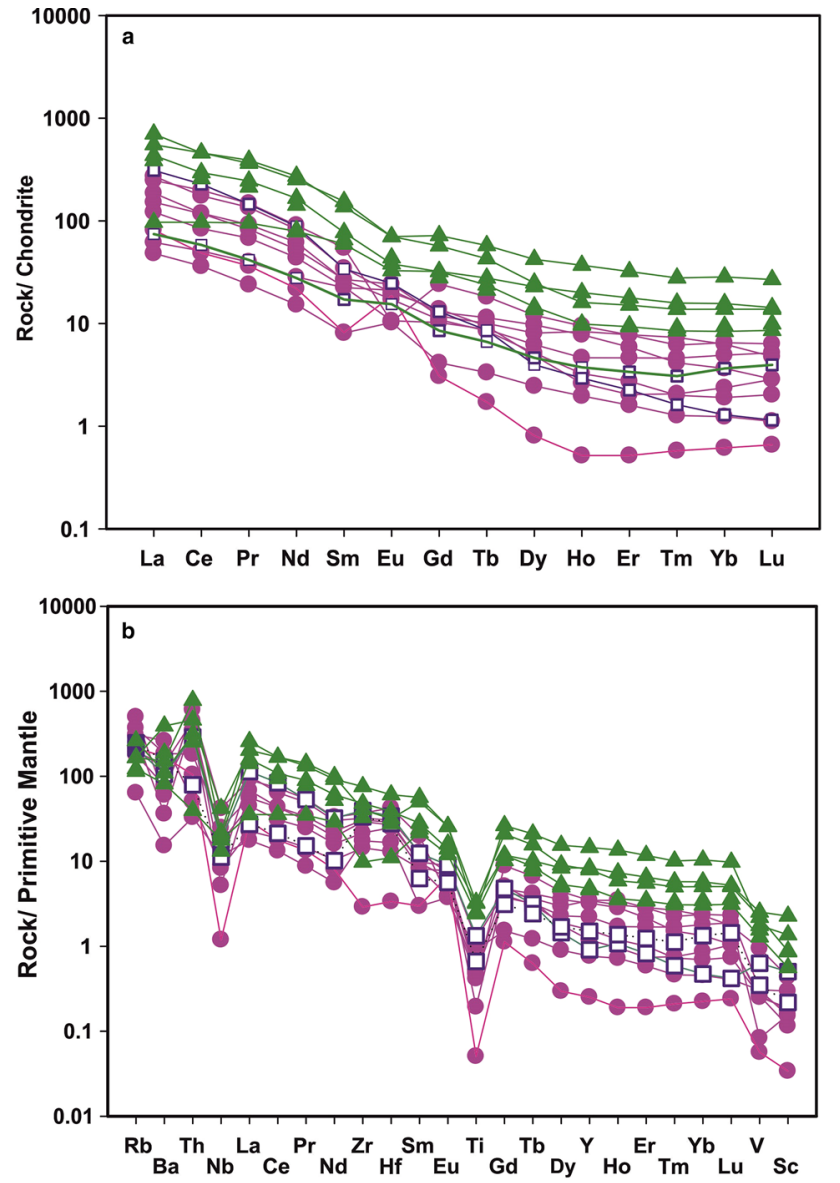

Figure 14. (a) Chondrite normalised REE plot (Sun and McDonough 1989). Near flat HREE and mild negative Eu anomalies indicate shallow melting conditions. (b) Primitive mantle normalised multi-elemental variation diagram (Sun and McDonough 1989) for the host granite, mixed zone and ME. The negative anomalies of HFSE suggest the arc signatures.

mechanism in generating the flow band structures in the Nalgonda granite (figure 3b). Mafic magma globules get diluted to linear or filament-like form and subsequently flown along with the convective flow of the host felsic magma and converted to more linear strips and banded forms. This magmatic compositional variation generated in liquid magmatic state was preserved while solidification accompanied crystallisation in the form of varying modal proportions of mafic and felsic phases and thus able to recognise as banded structures in the host granite.

In the Nalgonda granite, melanocratic MEs represent the second event of magma mixing, and they are distinct from the coexisting mesocratic ME. They are mostly angular in form and show sharp contact with the surrounding host granite. Features like rounded globule forms, diffusive contacts and cuspate margins are almost absent in these MEs. They do not form filament-like structures around it or linear deformation. The absence of these evidences indicates that while interacting, the mafic magma had high viscosity contrast with the host granite magma. They are characterised by the abundance of fine-grained amphibole and biotite indicating that the mafic magma was more water rich and underwent high nucleation rate that stabilised mafic phases due to thermal contrast with the host granite magma (figure 8a and d; e.g., Baxter and Feely 2002). The presence of mafic clots in fine-grained matrix indicates that mafic magma had partially crystallised before thermal quenching with the host granite magma (figure 8d). It is unique that melanocratic MEs are showing granite vein injection within it (figure 6a and b). The injected granite magma preserved their physical entity as veins and did not get homogenised with enclave magma (figure $6 \mathrm{a}$ and $\mathrm{b}$ ). This evidence also supports the above inference that enclave magma was more rigid in nature and had high viscosity contrast with the host granite magma. However, in some enclaves, these veins show ptygmatic folding (figure 6a) suggesting that enclave magma behaved plastically to fold the enclosed vein. Similarly, the injected granite magma cut across the enclaves and broke them apart into smaller one (figure 6a). These smaller broken enclaves also show sharp contact and plastic deformation (figure 6a) suggesting that mafic magma has got high viscosity contrast and did not mix effectively with the felsic host magma. The early mixing event and subsequent crystallisation solidification must have changed the host granite magma. Based on the above discussion, we conclude that magma mixing intensively occurred in the petrogenesis of Nalgonda granite on a magma chamber scale.

\subsection{Geochemical signatures of magma mixing}

Mixing between acidic host granite $\left(\mathrm{SiO}_{2}: 66-74\right.$ wt. $\% ; \mathrm{MgO}:<1.3$ wt. $\% ; \mathrm{Fe}_{2} \mathrm{O}_{3}$ : $<3.7$ wt. $\left.\%\right)$ and intermediate mafic $\left(\mathrm{SiO}_{2}: 57-63\right.$ wt.\%; $\mathrm{MgO}: 9-4$ wt.\%; $\mathrm{Fe}_{2} \mathrm{O}_{3}$ : 5-9 wt.\%) magmas were involved in the petrogenesis of Nalgonda granite. Chemical signatures like alkaline nature with high sodic content over potassium $\left(\mathrm{K}_{2} \mathrm{O} / \mathrm{Na}_{2} \mathrm{O}\right.$ : 0.6-0.94), high $\mathrm{MgO}$ (9-4 wt.\%), $\mathrm{Fe}_{2} \mathrm{O}_{3}$ (5-9 wt.\%) and Y (20-62 ppm) contents in ME rock indicate that parental magma 

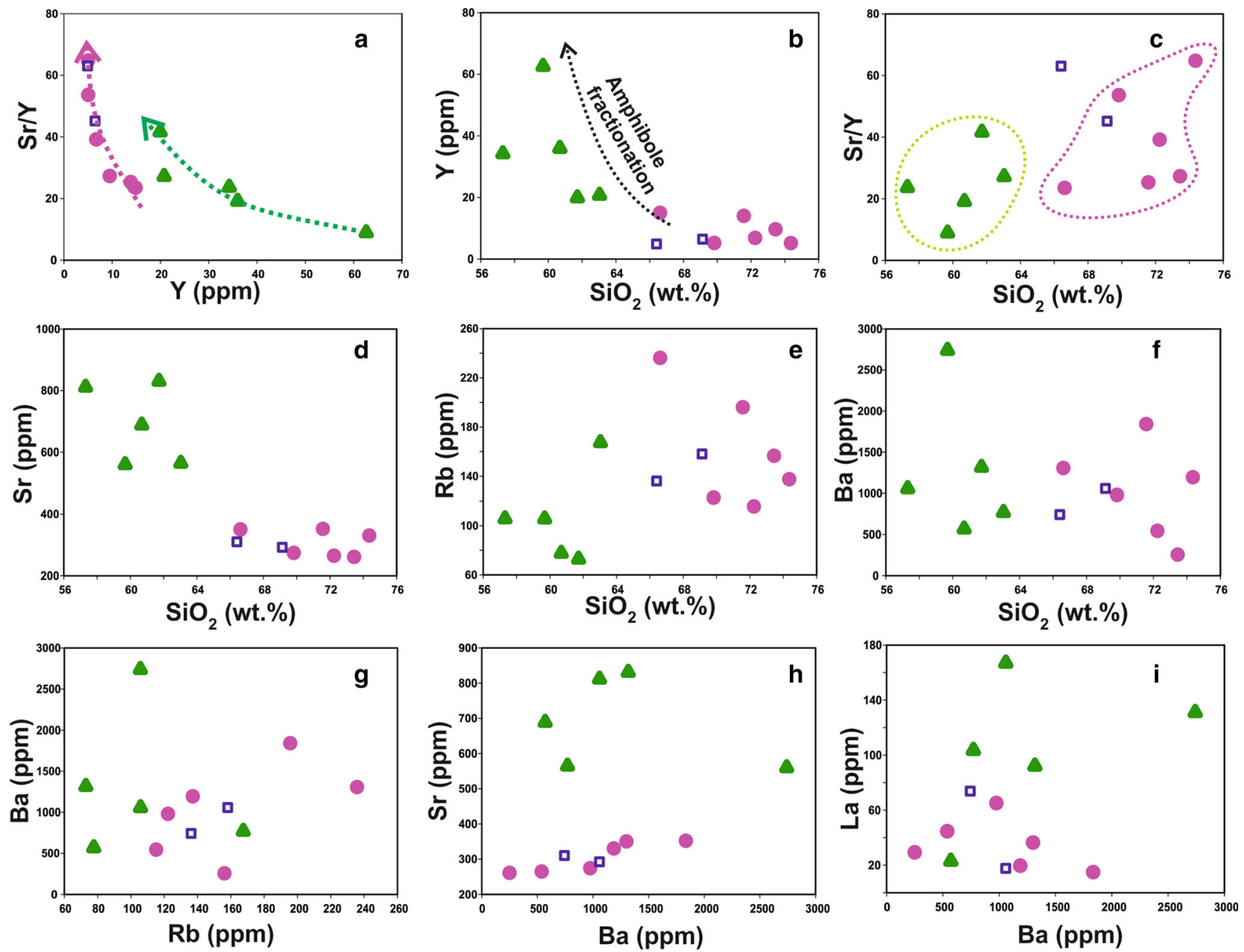

Figure 15. Geochemical plots to demonstrate fractional crystallisation and diffusive fractionation: (a) Sr/Y vs. Y plot where the ME and host granites show subparallel and overlapping increasing Sr/Y, suggesting that both magmas were evolved independently; (b) $\mathrm{SiO}_{2}$ vs. Y plot, wherein the differential variation trend of the host granites and ME suggests the role of fractional crystallisation; (c) $\mathrm{SiO}_{2}$ vs. Sr/Y plot, where both variants show overlapping and scattered relation, suggesting that apart from fractional crystallisation and mixing, some other processes were also operated during the mixing of two compositionally different magmas; $(\mathbf{d}-\mathbf{f})$ scattered distribution of $\mathrm{Sr}, \mathrm{Rb}$ and $\mathrm{Ba}$ for the MEs and host granite, suggesting that diffusive fractionation processes are associated with chaotic mixing of both felsic and mafic magmas; and (g-i) scattered distribution between the elements of similar diffusion coefficient to confirm the role of diffusive fractionation control in certain elements in the mixing processes of Nalgonda granite.

was sourced from a alkali-rich mafic source probably from the mantle, whereas in the host granite with high silica, potassic nature, very low $\mathrm{MgO}$, $\mathrm{Fe}_{2} \mathrm{O}_{3}$ and very low $\mathrm{Y}(5-14 \mathrm{ppm}), \mathrm{Cr}(<91 \mathrm{ppm})$ and $\mathrm{Ni}(<10 \mathrm{ppm})$ contents indicate that parental magma was generated from a crustal source. Distinct $\mathrm{Y}$ content in the host granite $(<20 \mathrm{ppm})$ and ME $(>20 \mathrm{ppm})$ strongly supports two different sources and melting of their parental magmas at different depths. Even though both magmas possess distinct geochemical source characteristics, there are common chemical composition like alkaline nature (figure 12a), enriched LILE, depleted
HFSE, negative $\mathrm{Nb}$ and $\mathrm{Ti}$ anomalies in spidergrams (figure 14b), and biotite mineral chemistry (figure 11) implies that subduction-related chemical signature was inherited from their source rocks. Lower $\mathrm{Sr} / \mathrm{Y}$ values (average $<40$ ) of the host granite and MEs further affirm the shallow to moderate melting conditions (Drummond and Defant 1990). The subduction origin for the evolution of Neoarchean granites in the EDC is reasonably well established (Dey et al. 2012; Mohan et al. 2013). In a more recent study on Neoarchean granitoids from the NW part of EDC (to the west of current study area), it is proposed that convergent margin 
tectonics are responsible for the evolution granitoids (Dey et al. 2017). Thus, it may be concluded that subduction was responsible for the widespread granitic activity across the EDC.

Mixing of magmas from different sources played a major role in the petrogenesis of granites that occur in Nalgonda region. Harker variation shows coherent linear trend between the host granite and $\mathrm{ME}$ rocks in their major oxides $(\mathrm{MgO}, \mathrm{Ca}$, $\mathrm{TiO}_{2}, \mathrm{MnO}, \mathrm{P}_{2} \mathrm{O}_{5}$ and $\left.\mathrm{K}_{2} \mathrm{O}\right)$ and trace element (Sc, V, Co, La and Y) contents. Such linear chemical trends between the two rock types justify the chemical mixing of two contrasting magmas and generated chemical gradient between two magmas (e.g., Kumar et al. 2017). Field evidences support that mafic magma globules were thoroughly mixed with the host granite magma by chaotic advection (figure 3a) and mechanical dilution in flow convection (figure 6a). Such mechanical mixing was enhanced by the chemical mixing between host granite and mafic magma (e.g., Kumar et al. 2017). The occurrence of mesocratic and wispy enclaves supports such chemical exchange (figure 4a and c). However, the individual mixed magmas have undergone some degree of fractional crystallisation as it is clearly indicated by the decreasing Harker variation trend of $\mathrm{Y}$, whereas in the host granite, such variation is not that well defined (figure 15b). Decreasing trend of $\mathrm{Y}$ is attributed to amphibole fractionation (e.g., Xiong et al. 2005). Clots of amphiboles in the enclave magma (figure 8e) suggest that amphibole was an early fractionating phase and caused the $\mathrm{Y}$ variation, whereas in the host granite, the absence of liquidus amphiboles keeps the $\mathrm{Y}$ variation minimum (figure 15b). Meanwhile, it is significant to notice that in $\mathrm{Sr} / \mathrm{Y} v s$. $\mathrm{Y}$ plot, both ME and host granites show subparallel and overlapping increasing trend of $\mathrm{Sr} / \mathrm{Y}$ ratio suggesting both magmas were evolved independently (figure 15a). However, with Harker variation, Sr/Y ratios of both rock types show overlapping and scattered relation (figure 15c). This indicates that apart from fractional crystallisation and mixing, some other processes were also operated during the mixing of two compositionally different magmas in the genesis of Nalgonda granite. In support of this inference, we observed that elements such as $\mathrm{Sr}, \mathrm{Rb}$ and $\mathrm{Ba}$ do not show linear Harker variation between the two rock types (figure $15 \mathrm{~d}-\mathrm{f}$ ). These elements has got large diffusion coefficient compared to Sc, V, Co, La and Y showing the linear variation trends (e.g., Perugini et al. 2006, 2008). The scattered variations of $\mathrm{Ba}, \mathrm{Rb}$ and
Sr can be attributed to the diffusive fractionation processes associated with chaotic mixing of both felsic and mafic magmas (Perugini et al. 2006, 2008). Because in mixing processes governed by chaotic advection, the degree of correlation between trace elements decreases as the difference in their diffusion coefficient increases with the mixing time (Perugini et al. 2006, 2008). The plots of elements with similar diffusion coefficient such as $\mathrm{Ba}$ vs. $\mathrm{Rb}, \mathrm{Sr}$ vs. $\mathrm{Ba}$ and $\mathrm{La}$ vs. $\mathrm{Ba}$ show large scatter (figure $15 \mathrm{~g}-\mathrm{i}$ ), thus indicating the probable role of diffusive fractionation control in certain elements in the mixing processes of Nalgonda granite (figure 15). From the various geochemical evidences, we conclude that Nalgonda granite has evolved through magma mixing, fractional crystallisation and diffusive fractionation and developed compositional heterogeneity.

\section{Conclusions}

Intensive magma mixing-mingling features at magma chamber scale are documented from the study area. MEs had interacted at two stages with acidic host granite, wherein the initial stage promoted efficient thorough mixing. The second stage of mafic magma mixing is incomplete due to the large viscosity contrast and resulted into preserve the physical entity of the end-members. Linear Harker variation of major and trace elements indicates that mixing has promoted to develop the chemical gradient between ME and host granite magmas. Mechanical dilution by chaotic advection has enhanced the chemical diffusion of both magmas. The role of fractional crystallisation is also envisaged. Diffusive fractionation was active during the chaotic advection mixing. It is concluded that heterogeneity in compositional variation of Nalgonda granite can be attributed to difference in the degree of mechanical dilution of mafic magma, fractional crystallisation and diffusive fractionation. The role of subduction in the evolution of these rocks is supported by geochemical systematics.

\section{Acknowledgements}

This work forms part of the PhD thesis of the first author. We are thankful to the Director, CSIRNGRI, for permitting to publish this work. SS acknowledges the CSIR-Shyama Prasad Mukherjee Fellowship to carry out this work. Thanks are 
due to Drs E V S S K Babu, D S Sarma, M Satyanarayanan and A Keshav Krishna for providing the mineral and whole-rock geochemical data. Thanks are due to Dr M L Renjith and an anonymous reviewer for the critical comments that helped to substantially improve the earlier version of this paper.

\section{References}

Abdel-Rahman A-F M 1994 Nature of biotites from alkaline, calc-alkaline, and peraluminous magmas; J. Petrol. 35(2) 525-541.

Ade-Hall J, Palmer H and Hubbard T 1971 The magnetic and opaque petrological response of basalts to regional hydrothermal alteration; Geophys. J. Int. 24(2) 137-174.

Barbarin B 1990 Plagioclase xenocrysts and mafic magmatic enclaves in some granitoids of the Sierra Nevada batholith, California J. Geophys. Res. Solid Earth 95(B11) 1774717756.

Barbarin B 2005 Mafic magmatic enclaves and mafic rocks associated with some granitoids of the central Sierra Nevada batholith, California: Nature, origin, and relations with the hosts; Lithos 80(1) 155-177.

Barbarin B and Didier J 1992 Genesis and evolution of mafic microgranular enclaves through various types of interaction between coexisting felsic and mafic magmas; Earth Environ. Sci. Trans. R. Soc. Edinburgh 83(1-2) 145-153.

Baxter S and Feely M 2002 Magma mixing and mingling textures in granitoids: Examples from the Galway Granite, Connemara, Ireland; Mineral. Petrol. 76(1) 63-74.

Beckinsale R, Drury S and Holt R 1980 3360-Myr old gneisses from the South Indian Craton; Nature 283(5746) 469.

Chadwick B, Vasudev V and Hegde G 2000 The Dharwar craton, southern India, interpreted as the result of Late Archaean oblique convergence; Precamb. Res. 99(1) 91111.

Chadwick B, Vasudev V and Hegde G 2003 The Chitradurga schist belt and its adjacent plutonic rocks, northwest of Tungabhadra, Karnataka: A duplex in the late Archaean convergent setting of Dharwar craton; J. Geol. Soc. India 69 5-24.

Chardon D, Jayananda M and Peucat J J 2011 Lateral constrictional flow of hot orogenic crust: Insights from the Neoarchean of south India, geological and geophysical implications for orogenic plateaux; Geochem. Geophys. Geosys. 12(2) 1-24.

Deer W A, Howie R A and Zussman J 1992 An introduction to the rock-forming minerals; Vol. 696, Longman Scientific \& Technical, Hong Kong.

Dey S, Pandey U K, Rai A K and Chaki A 2012 Geochemical and $\mathrm{Nd}$ isotope constraints on petrogenesis of granitoids from NW part of the eastern Dharwar craton: Possible implications for late Archaean crustal accretion; J. Asian Earth Sci. 45 40-56.

Dey S, Halla J, Kurhila M, Nandy J, Heilimo E and Pal S 2017 Geochronology of Neoarchaean granitoids of the NW eastern Dharwar craton: Implications for crust formation; Geol. Soc. London, Spec. Publ. 449(1) 89-121.

Drummond M S and Defant M J 1990 A model for trondhjemite-tonalite-dacite genesis and crustal growth via slab melting-Archean to Modern comparisons $J$. Geophys. Res.-Solid Earth Planets 95 21,503-21, 521.

Elangovan R, Krishna K, Vishwakarma N, Hari K and Mohan M R 2017 Interaction of coeval felsic and mafic magmas from the Kanker granite, Pithora region, Bastar Craton, Central India; J. Earth Syst. Sci. 126(7) 92.

Flinders J and Clemens J D 1996 Non-linear dynamics, chaos, complexity and enclaves in granitoid magmas; In: 3rd Hutton symposium, Vol. 87, pp. 277-283.

GSI 1994 Generalised geological map of Dharwar Craton; Geol. Surv. India, Kolkata.

GSI 1995 District resource map of Nalgonda region of EDC; Geol. Surv. India, Kolkata.

Henry D J, Guidotti C V and Thomson J A 2005 The Ti-saturation surface for low-to-medium pressure metapelitic biotites: Implications for geothermometry and Ti-substitution mechanisms; Am. Mineral. 90(2-3) 316328.

Hibbard M 1991 Textural anatomy of twelve magma-mixed granitoid systems, enclaves and granite petrology; Elsevier, Amsterdam, pp. 431-444.

Hibbard M J 1981 The magma mixing origin of mantled feldspars: Contributions to Mineral; Petroleum 76(2) $158-170$.

Jayananda M, Martin H, Peucat J-J and Mahabaleswar B 1995 Late Archaean crust-mantle interactions: Geochemistry of LREE-enriched mantle derived magmas. Example of the Closepet batholith, southern India; Contrib. Mineral. Petrol. 119(2) 314-329.

Jayananda M, Moyen J-F, Martin H, Peucat J-J, Auvray B and Mahabaleswar B 2000 Late Archaean (2550-2520 $\mathrm{Ma}$ ) juvenile magmatism in the Eastern Dharwar craton, southern India: Constraints from geochronology, Nd-Sr isotopes and whole rock geochemistry; Precamb. Res. 99(3) 225-254.

Jayananda M, Chardon D, Peucat J-J and Capdevila R $20062.61 \mathrm{Ga}$ potassic granites and crustal reworking in the western Dharwar craton, southern India: Tectonic, geochronologic and geochemical constraints; Precamb. Res. 150(1-2) 1-26.

Jayananda M, Kano T, Peucat J-J and Channabasappa S 2008 3.35 Ga komatiite volcanism in the western Dharwar craton, southern India: Constraints from Nd isotopes and whole-rock geochemistry; Precamb. Res. 162(1) 160-179.

Jayananda M, Peucat J-J, Chardon D, Rao B K, Fanning C and Corfu F 2013 Neoarchean greenstone volcanism and continental growth, Dharwar craton, southern India: Constraints from SIMS U-Pb zircon geochronology and $\mathrm{Nd}$ isotopes; Precamb. Res. 227 55-76.

Jayananda M, Gireesh R, Sekhamo K-U and Miyazaki T 2014 Coeval felsic and Mafic Magmas in neoarchean calcalkaline magmatic arcs, Dharwar craton, Southern India: Field and petrographic evidence from mafic to Hybrid magmatic enclaves and synplutonic Mafic dykes; J. Geol. Soc. India 84(1) 5-28.

Kumar S 2010 Mafic to hybrid microgranular enclaves in the Ladakh batholith, northwest Himalaya: Implications 
on calc-alkaline magma chamber processes; J. Geol. Soc. India 76(1) 5-25.

Kumar S, Rino V and Pal A 2004 Field evidence of magma mixing from microgranular enclaves hosted in Palaeoproterozoic Malanjkhand granitoids, central India; Gondwana Res. 7(2) 539-548.

Kumar S, Bora S and Sharma U K 2017 Early Cretaceous subvolcanic calc-alkaline granitoid magmatism in the Nubra-Shyok valley of the Shyok Suture Zone, Ladakh Himalaya, India: Evidence from geochemistry and U-Pb SHRIMP zircon geochronology; Lithos $\mathbf{2 7 7}$ $33-50$.

Laurent O, Martin H, Doucelance R, Moyen J-F and Paquette J-L 2011 Geochemistry and petrogenesis of high-K "sanukitoids" from the Bulai pluton, Central Limpopo Belt, South Africa: Implications for geodynamic changes at the Archaean-Proterozoic boundary; Lithos 123(1) $73-91$.

Laurent O, Martin H, Moyen J-F and Doucelance R 2014 The diversity and evolution of late-Archean granitoids: Evidence for the onset of "modern-style" plate tectonics between 3.0 and $2.5 \mathrm{Ga}$; Lithos 205 208-235.

Le Maitre R 1984 A proposal by the IUGS Subcommission on the systematics of igneous rocks for a chemical classification of volcanic rocks based on the total alkali silica (TAS) diagram: (on behalf of the IUGS Subcommission on the Systematics of Igneous Rocks); Austr. J. Earth Sci. 31(2) 243-255.

Meen J K, Rogers J J and Fullagar P D 1992 Lead isotopic compositions of the Western Dharwar Craton, southern India: evidence for distinct Middle Archean terranes in a Late Archean craton; Geochim. Cosmochim. Acta 56(6) 2455-2470.

Mohan M R, Piercey S J, Kamber B S and Sarma D S 2013 Subduction related tectonic evolution of the Neoarchean eastern Dharwar Craton, southern India: New geochemical and isotopic constraints; Precamb. Res. 227 204-226.

Nachit H, Ibhi A, Abia E H and Ohoud M B 2005 Discrimination between primary magmatic biotites, reequilibrated biotites and neoformed biotites; C. R. Geosci. 337(16) $1415-1420$.

Naqvi S M 2005 Geology and evolution of the Indian plate: From Hadean to Holocene, 4 Ga to 4 Ka; Capital Publ. Co., New Delhi.

Perugini D and Poli G 2000 Chaotic dynamics and fractals in magmatic interaction processes: A different approach to the interpretation of mafic microgranular enclaves; Earth Planet. Sci. Lett. 175 93-103.

Perugini D, Poli G and Gatta G D 2002 Analysis and simulation of magma mixing processes in 3D; Lithos 65 $313-330$

Perugini D, Poli G and Mazzuoli R 2003a Chaotic advection, fractals and diffusion during mixing of magmas: Evidence from lava flows; J. Volcanol. Geotherm. Res. 124 259-275.

Perugini D, Poli G, Christofides G and Eleftheriadis G 2003b Magma mixing in the Sithonia Plutonic Complex, Greece: Evidence from mafic microgranular enclaves; Contib. Mineral. Petrol. 178 173-200.

Perugini D, Petrelli M and Poli G 2006 Diffusive fractionation of trace elements by chaotic mixing of magmas; Earth Planet. Sci. Lett. 243 669-680.
Perugini D, DeCampos C P, Dingwell D B, Petrelli M and Poli G 2008 Trace element mobility during magma mixing: Preliminary experimental results; Chem. Geol. 256 146157.

Peucat J, Bouhallier H, Fanning C and Jayananda M 1995 Age of the Holenarsipur greenstone belt, relationships with the surrounding gneisses (Karnataka, South India); J. Geol. 103(6) 701-710.

Rajamanickam M, Balakrishnan S and Bhutani R 2014 $\mathrm{Rb}-\mathrm{Sr}$ and $\mathrm{Sm}-\mathrm{Nd}$ isotope systematics and geochemical studies on metavolcanic rocks from Peddavura greenstone belt: Evidence for presence of Mesoarchean continental crust in easternmost part of Dharwar Craton, India; J. Earth Syst. Sci. 123(5) 989-1011.

Ramakrishnan M and Swaminath J S 1981 Early Precambrian supracrustals of southern Karnataka; Vol. 112, Geol. Surv. India, Bengaluru.

Rao Y B, Sivaraman T, Pantulu G, Gopalan K and Naqvi S $1992 \mathrm{Rb}-\mathrm{Sr}$ ages of late Archean metavolcanics and granites, Dharwar Craton, South India and evidence for early Proterozoic thermotectonic event (s); Precamb. Res. 59(1-2) 145-170.

Reid Jr J B, Evans O C and Fates D G 1983 Magma mixing in granitic rocks of the central Sierra Nevada, California; Earth Planet. Sci. Lett. 66 243-261.

Renjith M, Charan S, Subbarao D, Babu E and Rajashekhar V 2014 Grain to outcrop-scale frozen moments of dynamic magma mixing in the syenite magma chamber, Yelagiri Alkaline Complex, South India; Geosci. Frontiers 5(6) 801-820.

Sarma D S, Fletcher I R, Rasmussen B, McNaughton N J, Mohan M R and Groves D I 2011 Archaean gold mineralization synchronous with late cratonization of the Western Dharwar Craton, India: $2.52 \mathrm{Ga} \mathrm{U}-\mathrm{Pb}$ ages of hydrothermal monazite and xenotime in gold deposits; Min. Dep. $46273-288$.

Shand S J 1947 Eruptive rocks, London; John Wiley \& Sons, New York.

Sun S-S and McDonough W-S 1989 Chemical and isotopic systematics of oceanic basalts: Implications for mantle composition and processes; Geol. Soc. London, Spec. Publ. 42(1) 313-345.

Turnbull R, Weaver S, Tulloch A, Cole J, Handler M and Irela T 2010 Field and geochemical constraints on MaficFelsic interactions, and processes in high-level Arc Magma Chambers: An example from the Halfmoon Pluton, New Zealand; J. Petrol. 51 1477-1505.

Vernon R 1984 Microgranitoid enclaves in granitesGlobules of hybrid magma quenched in a plutonic environment; Nature 309(5967) 438-439.

Vernon R 1990 Crystallization and hybridism in microgranitoid enclave magmas: Microstructural evidence; $J$. Geophys. Res.: Solid Earth 95(B11) 17849-17859.

Vigneresse J-L 2015 Textures and melt-crystal-gas interactions in granites; Geosci. Frontiers 6(5) 635-663.

Wiebe R and Hawkins D P 2015 Growth and impact of a Mafic-Silicic layered intrusion in the Vinalhaven Intrusive Complex, Maine; J. Petrol. 56 273-298.

Wiebe R, Smith D, Sturm M, King E and Seckler M 1997 Enclaves in the Cadillac Mountain granite (coastal Maine): Samples of hybrid magma from the base of the chamber; J. Petrol. 38(3) 393-423. 
Xiong X, Adam J and Green T 2005 Rutile stability and rutile/melt HFSE partitioning during partial melting of hydrous basalt: Implications for TTG genesis; Chem. Geol. 218(3) 339-359.

Corresponding editor: N V Chalapathi RAO
Yang J-H, Wu F-Y, Chung S-L, Wilde S A and Chu M-F 2006 A hybrid origin for the Qianshan A-type granite, northeast China: Geochemical and $\mathrm{Sr}-\mathrm{Nd}-\mathrm{Hf}$ isotopic evidence; Lithos 89(1) 89-106. 